\title{
3-Formylchromones as diverse building blocks in heterocycles synthesis
}

\author{
Magdy Ahmed Ibrahim, Tarik El-Sayed Ali *, \\ Nasser Mohamed El-Gohary, and Azza Mohamed El-Kazak
}

Department of Chemistry, Faculty of Education, Ain Shams University, Roxy, 11711, Cairo, Egypt

*Corresponding author at: Department of Chemistry, Faculty of Education, Ain Shams University, Roxy, 11711, Cairo, Egypt. Tel.: +2.01.003730144; fax: +2.02.2581243. E-mail address: tarikelsayed1975@yahoo.com (T.E. Ali).

\section{REVIEW INFORMATION}

Received: 29 April 2013

Accepted: 03 June 2013

Online: 30 September 2013

\section{KEYWORDS}

Addition reactions

Ring transformation

3-Formylchromones

$\gamma$-Pyrone ring opening

Condensation reaction

Carbon and nitrogen nucleophiles

\section{Introduction}

Chromone derivatives are widely known as an important class of biologically active compounds. The chemical reactivity of 3-substituted chromones is widely different depending on the nature of the functional group present at the position 3 and the reaction conditions. Among the 3-functionalized chromones, their 3-formyl derivatives are widely used in heterocyclic synthesis. 3-Formylchromones are also known as 4-oxo-4H-1-benzopyran-3-carboxaldehydes, 4-oxo-4H-chromene-3-carboxaldehydes and chromone-3-carboxaldehydes. Although many methods are known for the synthesis of 3formylchromones, Vilsmeier-Haack reaction on substituted 2hydroxyacetophenones is the most suitable among them [1-17]. In Vilsmeier-Haack reaction, the reaction takes place via double formylation of $o$-hydroxyacetophenones followed by cycloaddition with concomitant dehydration (Scheme 1). DMF- $\mathrm{POCl}_{3}$ plays a dual role of a reagent as well as a solvent. A variety of substituted 3-formylchromones $\mathbf{1 a - z}$ were prepared under traditional and microwave irradiation using Vilsmeier-Haack reagent and are reported herein.

\section{Chemical reactivity of 3-formylchromones}

3-Formylchromones, 1a-z, are a versatile synthons for the synthesis of a variety of novel heterocyclic systems possessing diverse biological activities. From a synthetic view point, 3formylchromones,1a-z, occupy an important position in the synthesis of various heterocyclic systems, due to the availability of three electron deficient sites, the aldehydes carbon, C-2 carbon, and the C- 4 carbon of the carbonyl group. Also, 3-formylchromones are able to serve as a heterodiene as well as a dienophile or a Michael acceptor. Moreover, a variety of fused heterocycles were prepared directly from the reaction of compounds 1a-z with some bifunctional nucleophiles. The present review aims to study the chemical reactivity of 3- formylchromones towards a variety of carbon and nitrogen nucleophiles under different reaction conditions.

\subsection{Chemical reactivity of 3-formylchromones towards active methyl and methylene compounds}

\subsubsection{Condensation reactions with active methyl compounds}

Condensation reactions of 3-formylchromone $\mathbf{1 a - c}, \mathbf{h}$ with substituted acetophenone $\mathbf{2}$ in freshly distilled pyridine or glacial acetic acid containing perchloric acid afforded substituted 3-(3-oxo-3-arylprop-1-enyl)chromones, 3 (Scheme 2) [18-21].

4-Hydroxy-1-alkyl-3-[3-(4-oxo-4H-chromen-3-yl)]quinolin$2(1 H)$-ones (5) were smoothly obtained via a Knoevenagel condensation of 3-formylchromone (1a) with 3-acetyl-4hydroxy-1-alkylquinolin-2(1H)-one (4) in ethanol containing piperidine as basic catalyst (Scheme 3) [22,23].

Interaction of equimolar amount of 3-formyl-6chlorochromone (1c) with 4-acetyl-5,6-diphenylpyridazin$3(2 \mathrm{H})$-one $(6)$ in sodium ethoxide afforded 4-[3-(6-chloro-4oxochromen-3-yl)prop-2-enoyl]-5,6-diphenylpyridazin-3(2H)one (7) in $87 \%$ yield. When this reaction was carried out in ethanol containing few drops of piperidine, 7-(6-chloro-4oxochromen-3-yl)-3,4-diphenyl-6,7-dihydropyrano[2,3-c]pyraidazin-5-one (8) was obtained in 55\% yield, via intramolecular cycloaddition reaction in compound 7 (Scheme 4) [24].

Treating 3-formylchromones 1a-c with 5-acetylbarbituric acid (9a) and 5-acetylthiobarbituric acid (9b), in ethanol containing pyridine or water-Zn(L-proline) $)_{2}$ gave the corresponding $\alpha, \beta$-unsaturated ketones, 10a,b (Scheme 5) [25].

Similarly, treating 3-formylchromones 1a,b with 5 -acetyl1,3-dimethylbarbituric acid (11) under the same reaction conditions afforded 1-(1,3-dimethyl-2,4,6-pyrimidinetrione-5yl)-3-(4-oxo-4H-chromen-3-yl)-2-propen-1-one (12a) and

European Journal of Chemistry 


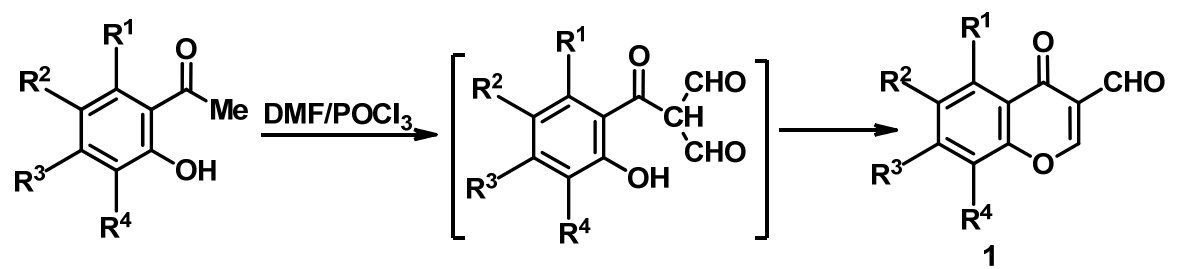

\begin{tabular}{|c|c|c|c|c|c|c|}
\hline 1 & $\mathbf{R}^{1}$ & $\mathbf{R}^{2}$ & $\mathbf{R}^{3}$ & $\mathbf{R}^{4}$ & Yield (\%) & M.p. $\left({ }^{\circ} \mathrm{C}\right)$ \\
\hline $\mathrm{a}$ & $\mathrm{H}$ & $\mathrm{H}$ & $\mathrm{H}$ & $\mathrm{H}$ & 63 & $150-151$ \\
\hline $\mathrm{b}$ & $\mathrm{H}$ & $\mathrm{Me}$ & $\mathrm{H}$ & $\mathrm{H}$ & 65 & $174-175$ \\
\hline $\mathrm{c}$ & $\mathrm{H}$ & $\mathrm{Cl}$ & $\mathrm{H}$ & $\mathrm{H}$ & 72 & $166-168$ \\
\hline $\mathrm{d}$ & $\mathrm{H}$ & $\mathrm{Br}$ & $\mathrm{H}$ & $\mathrm{H}$ & 57 & $190-191$ \\
\hline $\mathrm{e}$ & $\mathrm{H}$ & $\mathrm{F}$ & $\mathrm{H}$ & $\mathrm{H}$ & 76 & $155-160$ \\
\hline $\mathrm{f}$ & $\mathrm{H}$ & $\mathrm{OH}$ & $\mathrm{H}$ & $\mathrm{H}$ & 55 & $210-212$ \\
\hline $\mathrm{g}$ & $\mathrm{H}$ & $\mathrm{NO}_{2}$ & $\mathrm{H}$ & $\mathrm{H}$ & 82 & $253-254$ \\
\hline $\mathrm{h}$ & $\mathrm{H}$ & $\mathrm{H}$ & $\mathrm{OH}$ & $\mathrm{H}$ & 41 & 269 \\
\hline $\mathrm{i}$ & $\mathrm{H}$ & $\mathrm{H}$ & $\mathrm{OMe}$ & $\mathrm{H}$ & 62 & $188-190$ \\
\hline j & $\mathrm{H}$ & $\mathrm{OMe}$ & $\mathrm{H}$ & $\mathrm{H}$ & 65 & $174-175$ \\
\hline $\mathrm{k}$ & $\mathrm{H}$ & $\mathrm{H}$ & $\mathrm{H}$ & allyl & 42 & $73-74$ \\
\hline 1 & $\mathrm{H}$ & $\mathrm{Me}$ & $\mathrm{Me}$ & $\mathrm{H}$ & 63 & $192-193$ \\
\hline $\mathrm{m}$ & $\mathrm{Me}$ & $\mathrm{H}$ & $\mathrm{Me}$ & $\mathrm{H}$ & 68 & $145-147$ \\
\hline $\mathrm{n}$ & $\mathrm{H}$ & $\mathrm{Me}$ & $\mathrm{H}$ & $\mathrm{Me}$ & 61 & $187-190$ \\
\hline o & $\mathrm{H}$ & $\mathrm{Me}$ & $\mathrm{H}$ & $\mathrm{Cl}$ & 69 & $170-171$ \\
\hline $\mathrm{p}$ & $\mathrm{H}$ & $\mathrm{Me}$ & $\mathrm{Cl}$ & $\mathrm{H}$ & 45 & $166-167$ \\
\hline $\mathrm{q}$ & $\mathrm{H}$ & $\mathrm{Cl}$ & $\mathrm{H}$ & $\mathrm{Cl}$ & 46 & $169-174$ \\
\hline $\mathrm{r}$ & $\mathrm{H}$ & $\mathrm{Br}$ & $\mathrm{H}$ & $\mathrm{Br}$ & 40 & $177-178$ \\
\hline $\mathrm{s}$ & $\mathrm{H}$ & $\mathrm{Cl}$ & $\mathrm{H}$ & $\mathrm{NO}_{2}$ & 67 & 108 \\
\hline $\mathrm{t}$ & $\mathrm{H}$ & $\mathrm{Cl}$ & $\mathrm{H}$ & $\mathrm{Br}$ & 65 & 155 \\
\hline $\mathrm{u}$ & $\mathrm{H}$ & $\mathrm{Me}$ & $\mathrm{H}$ & $\mathrm{NO}_{2}$ & 69 & 180 \\
\hline $\mathrm{V}$ & $\mathrm{H}$ & $\mathrm{Me}$ & $\mathrm{H}$ & $\mathrm{Br}$ & 66 & 145 \\
\hline w & $\mathrm{H}$ & $\mathrm{NO}_{2}$ & $\mathrm{H}$ & $\mathrm{Br}$ & 63 & 81 \\
\hline $\mathrm{x}$ & $\mathrm{H}$ & $\mathrm{OH}$ & $\mathrm{H}$ & $\mathrm{H}$ & 68 & 198 \\
\hline $\mathrm{y}$ & $\mathrm{H}$ & $\mathrm{H}$ & $\mathrm{OH}$ & $\mathrm{NO}_{2}$ & 64 & 162 \\
\hline $\mathrm{z}$ & $\mathrm{H}$ & $\mathrm{H}$ & $\mathrm{OH}$ & $\mathrm{Br}$ & 74 & 210 \\
\hline
\end{tabular}

Scheme 1

1-(1,3-dimethyl-2,4,6-pyrimidinetrione-5-yl)-3-(6-methyl4-oxo-4H-chromen-3-yl)-2-propen-1-one (12b), respectively (Scheme 6) [26].

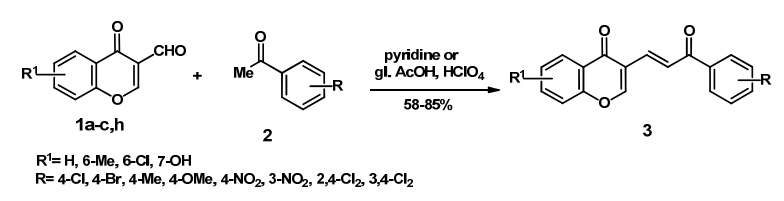

Scheme 2

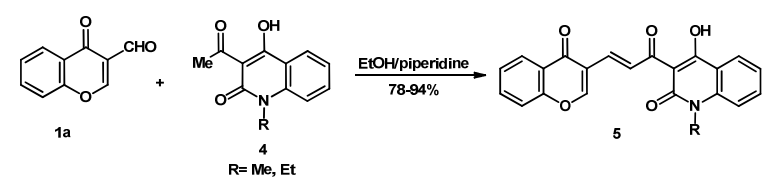

Scheme 3

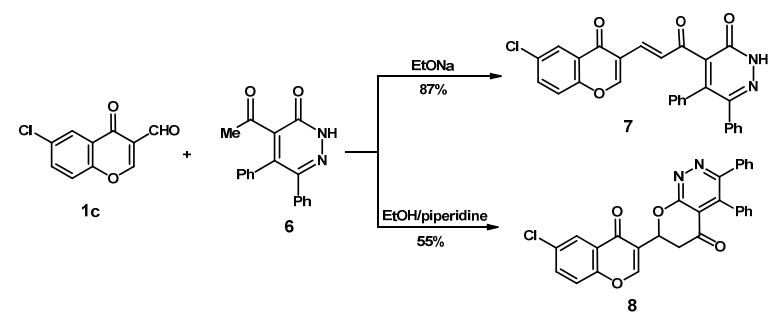

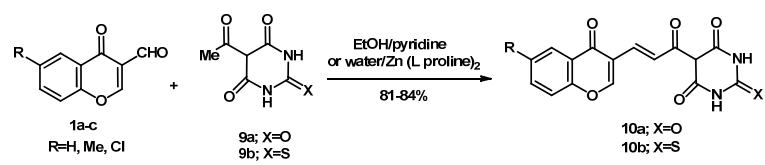

Scheme 5

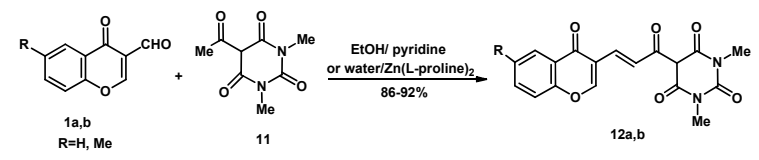

Scheme 6

Condensation of 3-formylchromones 1a-c with dehydroacetic acid (13) in ethanol containing pyridine or water-Zn(L-proline) 2 gave $\alpha, \beta$-unsaturated ketones 14 in high yields (87-92\%) (Scheme 7) [26].

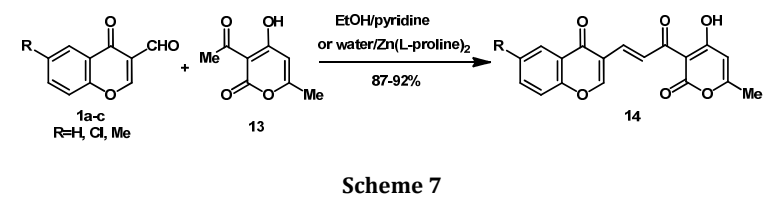

Refluxing 3-formylchromones 1a-c with 3-acetyl-4hydroxycoumarin (17) in ethanol containing pyridine as a basic catalyst gave 1-(4-hydroxychromen-2-one-3-yl)-3-(chromen-4one-3-yl)-2-propen-1-ones (18) in 65-92\% yields (Scheme8) [26,27]. 


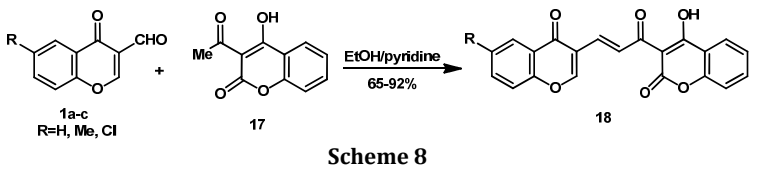

Reaction of 6,8-dichloro-3-formylchromone (1q) with 4methyl-2-oxo-2 $H$-chromone-3-carbonitrile (19) gave the addition product $\mathbf{2 0}$ as recently reported by El-Shaaer [28]. While Melikyan et al. [29] isolate the condensation products 21 on the reaction of $\mathbf{1 a - d}$ with compound $\mathbf{1 9}$ in refluxing toluene (Scheme 9).

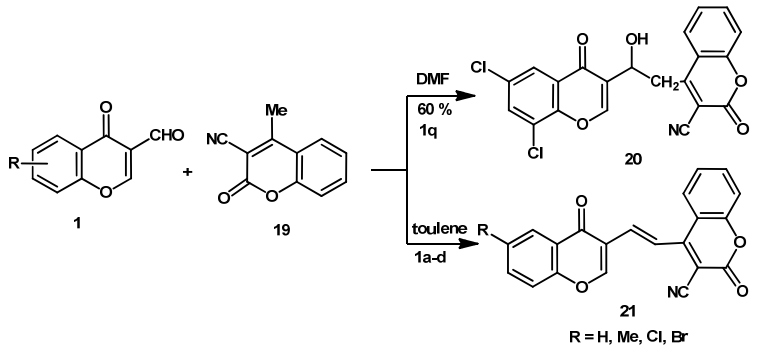

Scheme 9

Condensation of 3-formylchromone (1a) with 2-methyl-3acetylchromones $\mathbf{2 2}$ in acetic anhydride-potassium acetate led to bis-chromonylethylene 23 (Scheme 10). This reaction occurred only at 2-methyl group [30].

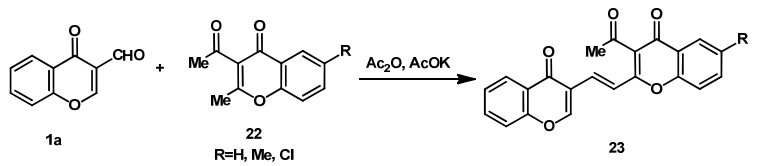

Scheme 10

2-(4-0xo-4H-chromen-3-yl)vinylthiazoline (24) was synthesized by condensation of 3-formylchromone 1a with 2methylthiazoline in glacial acetic acid containing sodium acetate (Scheme 11) [31].

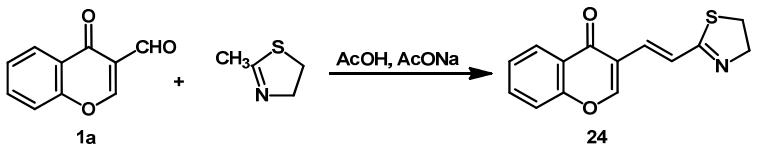

Scheme 11

Condensation of 3-formylchromone (1a) with 4,5,5trimethyl-2,5-dihydrofuran-2-ones 25 and 4,6,6-trimethyl-5,6dihydropyran-2-ones $\mathbf{2 6}$ in acetic anhydride yielded the condensation products $\mathbf{2 7}$ and $\mathbf{2 8}$, respectively (Scheme 12) [29].

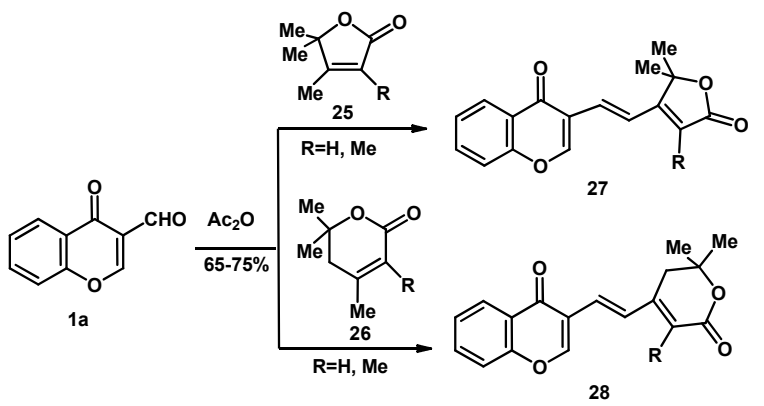

Scheme 12
3-Formylchromones 1b,c reacted with 2methylbenzimidazole 29a and 2-methylbenzothiazole 29b in dry DMSO and boric acid to give the addition products $\mathbf{3 0 a}, \mathbf{b}$ when the reactiontook place at $60{ }^{\circ} \mathrm{C}$, but when the reaction took place at $120^{\circ} \mathrm{C}$ afforded the condensation products $\mathbf{3 1 a}, \mathbf{b}$ (Scheme 13) [32].

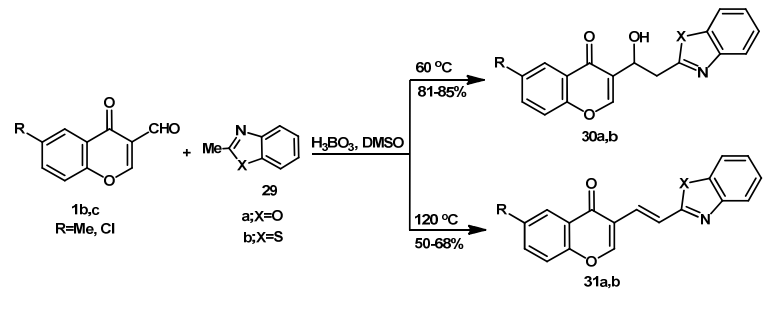

Scheme 13

Condensation of aldehydes 1a,b with 2-methylbenzothiazolium halides $\mathbf{3 2}$ in boiling acetonitrile gave chromenylbenzothiazolium derivatives 33 (Scheme 14) [33].

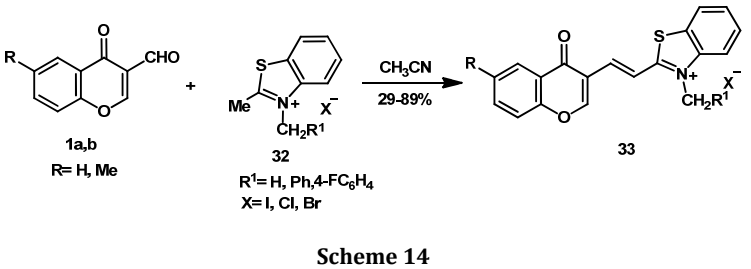

Treatment of 3-formylchromone 1a with 3-aryl-2-methyl$4(3 H)$-quinazolinones (34) in glacial acetic acid containing fused sodium acetate led to the condensed product $\mathbf{3 5}$ (Scheme 15) [33].

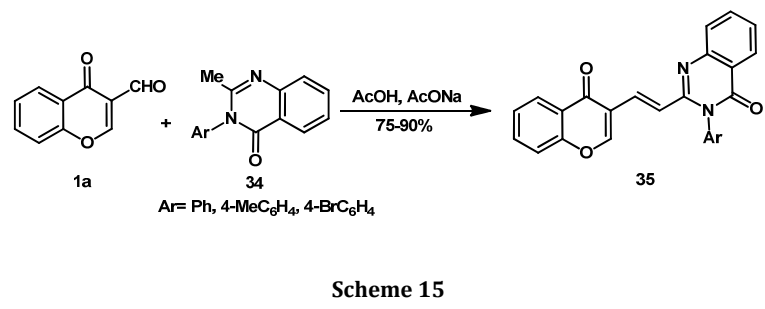

As a result of the above reactions, a variety of chromone derivatives bearing various heterocyclic systems were obtained from the condensation of 3 -formylchromones with some active methyl compounds either under acidic or basic conditions.

\subsubsection{Condensation reactions with acyclic active methylene compounds}

3-Styrylchromone 37, which is associated with important biological activities, was obtained by the condensation of 4 nitrotoluene or 4-nitrophenylacetic acid 36 with 3-formylchromone 1a in dry pyridine (Scheme 16) [34,35].

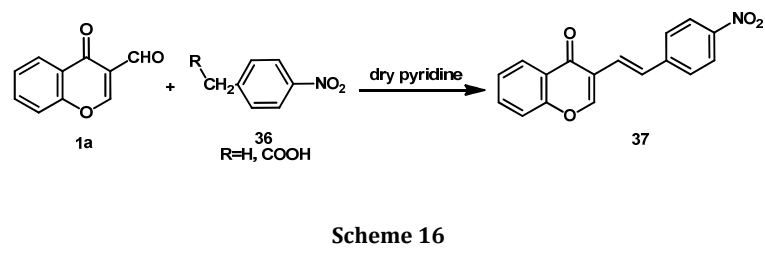

Synthesis of trans $\beta$-(chromon-3-yl)acrylic acids $\mathbf{3 8}$ were made by simple Knoevenagel condensation of 3-formyl- 
chromones $\mathbf{1 a}, \mathbf{b}, \mathbf{k}$ with malonic acid in dry pyridine under reflux (Scheme 17) [17,36-38].

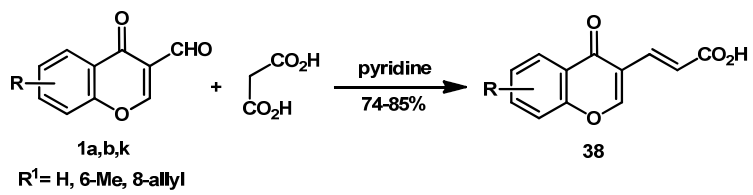

Scheme 17

6,8-Dimethylcoumarin-4-acetic acid (39) gave 3-styrylchromones $\mathbf{4 0}$ when reacted with 3-formyl-chromones $\mathbf{1 a , b}$ in boiling pyridine, via condensation followed by decarboxylation under the reaction conditions (Scheme 18) [39].

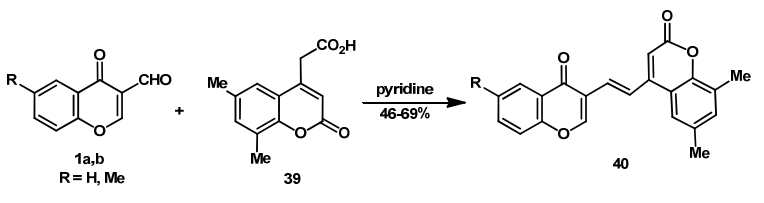

Scheme 18

In the same manner, 3-formylchromones 1a-c reacted with benzo[ $[d]$ isoxazol-3-ylacetic acid (41) in dry pyridine under reflux to give 3-(2-benzo[d] isoxazol-3-ylvinyl)-chromon-4-ones 42 in51-62\% yields (Scheme 19) [40].

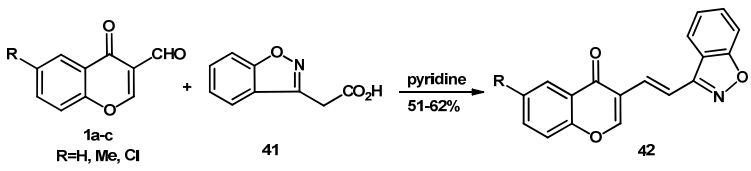

Scheme 19

Heating equimolar quantities of 3 -formylchromones $\mathbf{1 a , b}$ and phenylacetic acids 43 in acetic anhydride containing catalytic amounts of sodium acetate or potassium carbonate gave methyl 2-oxo- $2 H, 5 H$-pyrano[3,2-c]chromen-5-yl acetates $\mathbf{4 4}$ in $48-85 \%$ yields (Scheme 20), [41-43] while Shingare et al. [44] reported the formation of compounds $\mathbf{4 5}$ in $47-68 \%$ yields in acetic anhydride containing piperidine as a catalyst, the spectral data showed the presence of acetyl instead of the carboxy group, which could be explained by decarboxylation followed by acetylation in situ (Scheme 20).

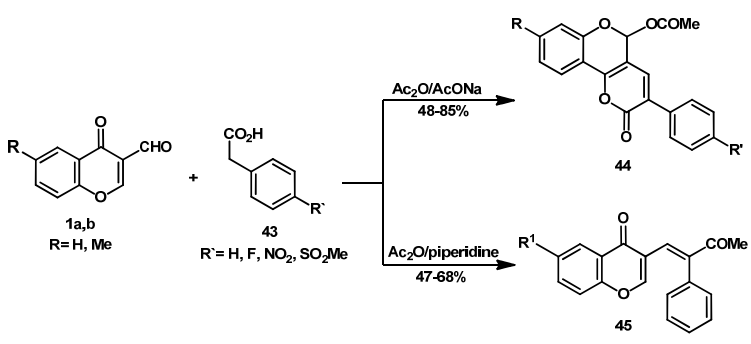

Scheme 20

Condensation of 3-formylchromones 1a-c,g with 3- or 4coumarinylacetic acids in acetic anhydride in the presence of potassium acetate either by heating at $90-100{ }^{\circ} \mathrm{C}$ or by microwave irradiation produced compounds 46 and 47, respectively (Scheme 21) [41].

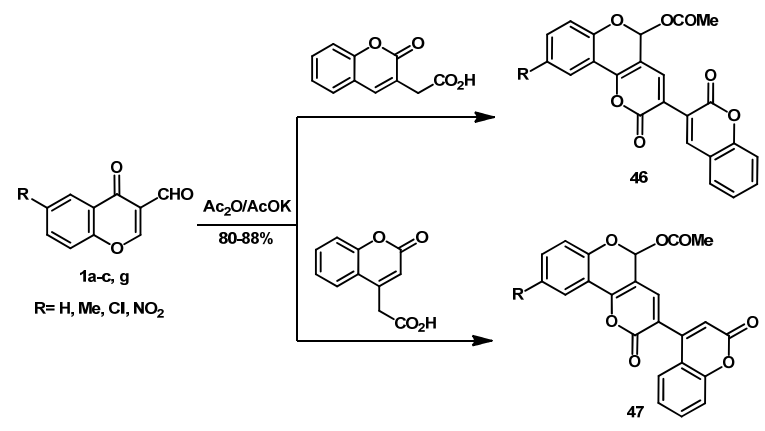

Scheme 21

Reactions of 3-formylchromones 1a-c with 4-substituted phenylselenylacetic acids $\mathbf{4 8}$ in acetic anhydride containing potassium acetate yielded 3-(phenylselenyl)-2-oxo- $2 \mathrm{H}, 5 \mathrm{H}$ pyrano[3,2-c]chromen-5-yl acetates 49 and not the other expected products $\mathbf{5 0}$ (Scheme 22) [45].

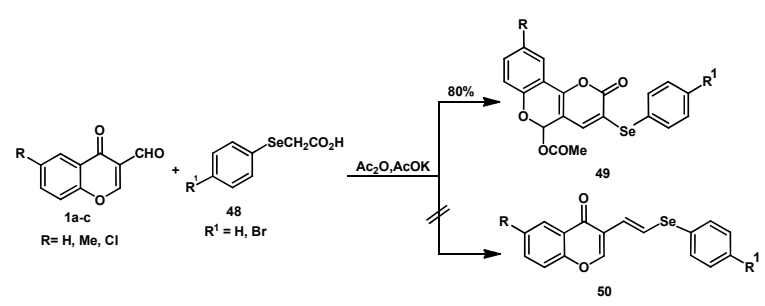

Scheme 22

Synthesis of trans- $\beta$-(4-oxo- $4 H$-chromen-3-yl)acrylonitrile 51 was made by simple condensation of 3 -formylchromones 1a,b with cyanoacetic acid in dry pyridine under reflux (Scheme 23) [46,47].

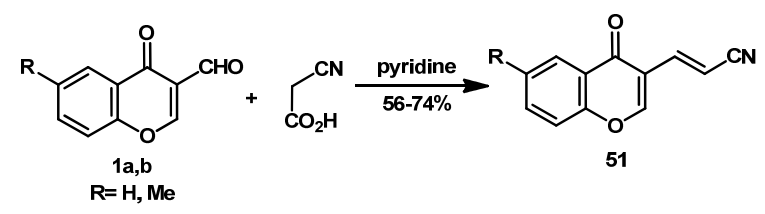

Scheme 23

Condensation of 3-formylchromones 1a,b,d with $p$ nitrobenzyl cyanide and 1-naphthyl-acetonitrile in the presence of $\mathrm{Ac}_{2} \mathrm{O} / \mathrm{AcOK}$ or $\mathrm{Ac}_{2} \mathrm{O} / \mathrm{AcONa}$ afforded the corresponding condensation products 52 and $\mathbf{5 3}$, respectively (Scheme 24) [48].

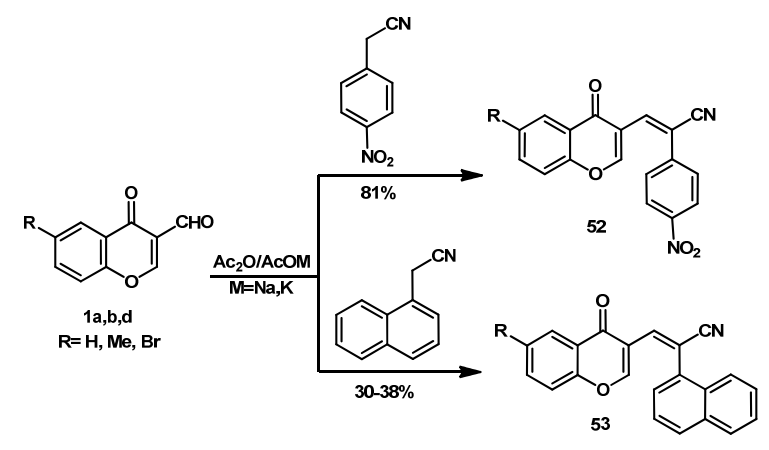

Scheme 24 
Similarly, condensation of 3-formychromones 1a, with tetrazolyl-p-nitrotoluene (54) in dry pyridine gave 3-[2-(4nitrophenyl)-2-(1H-tetrazol-5-yl)vinyl)]-4H-chromen-4-one (55) (Scheme 25) [49].

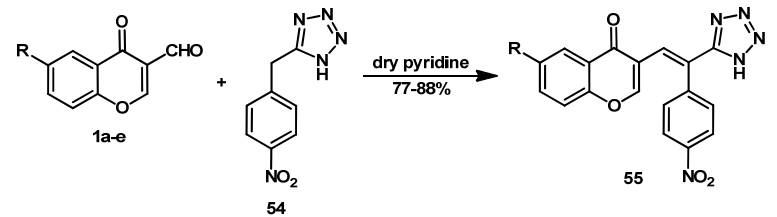

Scheme 25

3-Formylchromones 1a-c condensed with 1-(2,4difluorophenyl-2-[1,2,4]triazol-4-yl]ethanone (56) in acetic anhydride containing anhydrous sodium acetate to afford 3-[3(2,4-difluorophenyl)-3-oxo-2-[1,2,4] triazol-4-yl)propenyl] chromon-4-ones (57) (Scheme 26) [50].

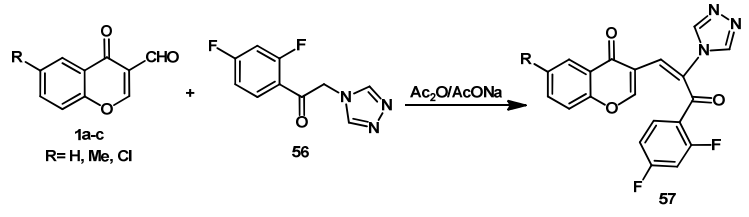

Scheme 26

Knoevenagel condensation of 3-formyl-7-methoxy chromone 1i with ethyl 3-(6-methoxy-1,3-benzodioxol-5-yl) propanoate $\mathbf{5 8}$ gave ethyl ester $\mathbf{5 9}$ (Scheme 27) [51].

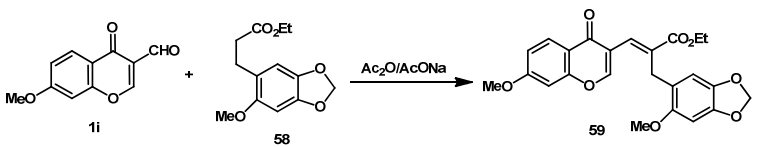

Scheme 27

Condensation of 3-formylchromones $\mathbf{1 a}, \mathbf{b}, \mathbf{d}, \mathbf{j}$ with phenacyl aryl sulfones 60, in glacial acetic acid and acetic anhydride in the presence of benzylamine as catalyst, yielded 1-(aroyl)-1(arylsulfonyl)- 2-[4-oxo-4H-chromen-3-yl] ethenes 61 (Scheme 28) [52].

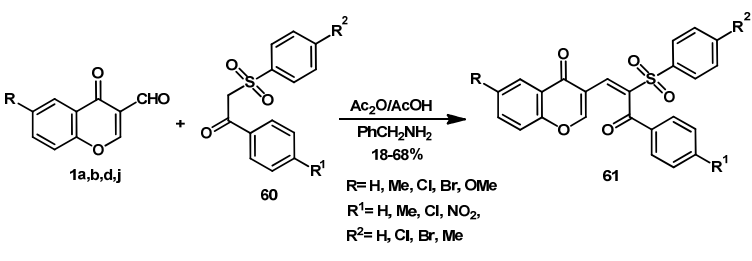

Scheme 28

When 3-formylchromone (1a) was treated with 5-nitro furyl trichloromethyl sulfone (62), in glacial acetic acid in the presence of ammonium acetate and piperidine, gave the condensation product 63 (Scheme 29) [52].

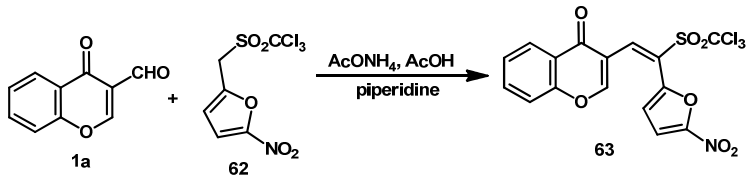

Scheme 29
Condensation product 64 was synthesized by reaction of 3 formylchromones $\mathbf{1 a}, \mathbf{b}, \mathbf{c}, \mathbf{g}$ and 2,4-pentanedione in acetic anhydride containing sodium acetate. While, acid catalyzed 1,4 addition of the enol form of 2,4-pentanedione to 3-formyl chromones 1a,b,c,g followed by ring opening and enolization afforded 5-benzoyl-2-hydroxyacetophenones 65 (Scheme 30) $[53,54]$.

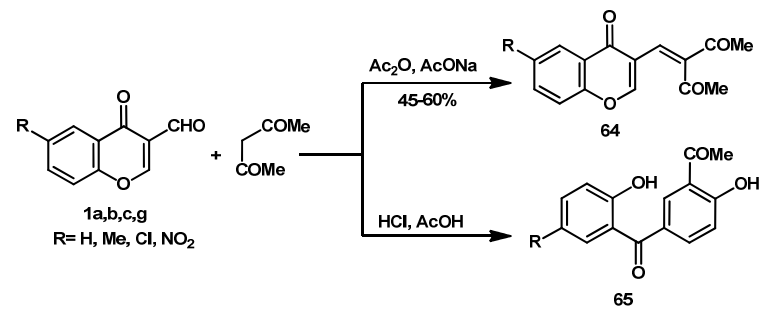

Scheme 30

Treatment of 3-formylchromone (1a) with ethyl acetoacetate in acetic anhydride containing sodium acetate yielded 3-(4-oxo-4H-1-chromen-3-yl)-2-(1-oxoethyl)-2propenoic acid ethyl ester (66) in $62 \%$ yield. However, when the reaction was carried out with a (1:2) excess of the reagent using piperidine in ethanol, 5-(2-hydroxybenzoyl)-2methylbenzene-1,3-dicarboxylic acid diethyl ester (67) was isolated in $80 \%$ yield (Scheme 31) [54,55].

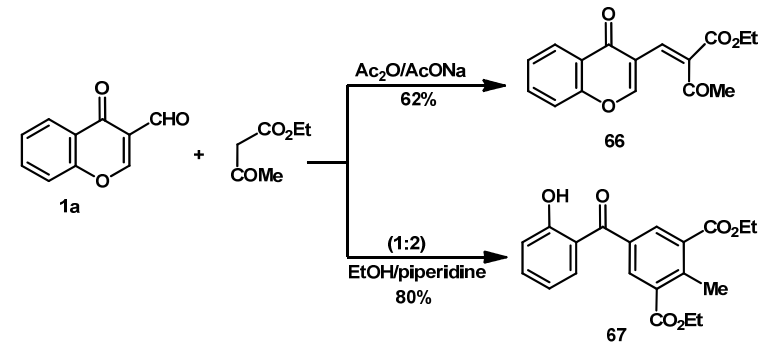

Scheme 31

Knoevenagel condensation of 3-formylchromones 1a-c with malononitrile, cyanoacetic acid and cyanoacetamide were carried out in various solvents such as water, ethanol, methanol, DMF, DMSO and toluene (Scheme 32). Among these solvents, water was found to be the best solvent for the reaction to produce ylidenenitriles 68 in excellent yields [56].

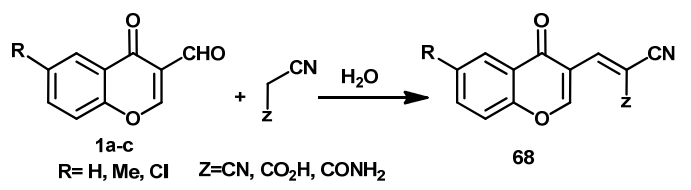

Scheme 32

Reaction of aldehyde 1a-c with chloroacetone in basic medium gave a mixture of arylidine $69(22-32 \%)$ and $o$ hydroxyphenyl furyl ketone 70 (Scheme 33) [57].

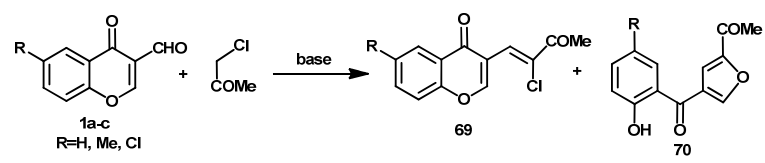

Scheme 33 
Condensation of 3-formylchromones 1a-c with diethyl malonate in acetic anhydride containing sodium acetate gave diethyl arylidine ester $\mathbf{7 1}$ in 74-80\% yield (Scheme 34) [58].

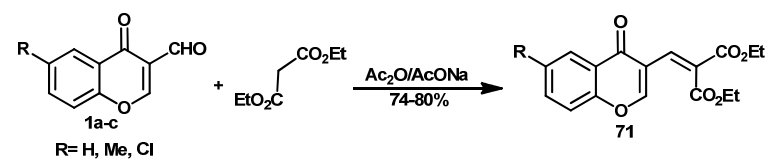

Scheme 34

Treatment of 3-formylchromone (1a) with 3(4 ,5'-dihydro4 -oxo-1`-phenylpyrazolo [3,4-d]pyrimidin-5`-yl)-3oxopropionic acid ethyl ester (72) in ethanol containing piperidine afforded 3-\{(4-oxo- $4 H$-chromen-3-yl)-2-(4,5dihydro-4-oxo-1-phenylpyrazolo $[3,4-d]$ pyrimidine-5 ${ }^{`}$ carbonyl\}acrylic acid ethyl ester (73) (Scheme 35) [59].

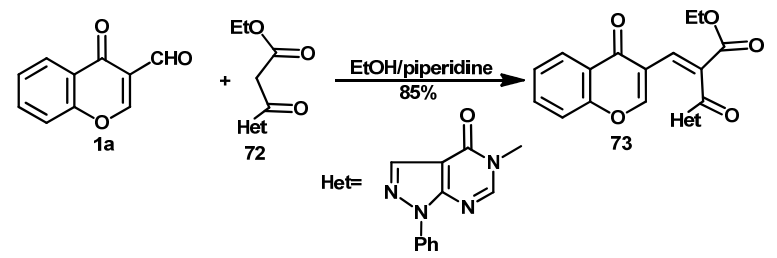

Scheme 35

3-Formylchromone (1a) reacted with acetamides $\mathbf{7 4}$ in dry pyridine to afford a mixture of chromenopyridones $\mathbf{7 5}$ and pyridone derivatives 76 (Scheme 36) [60,61].

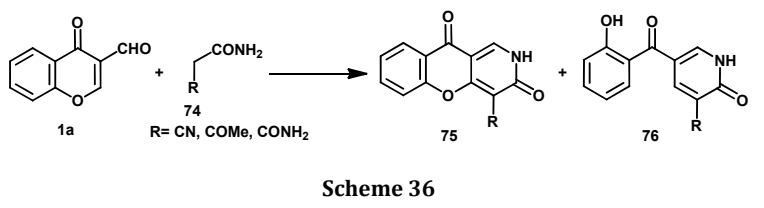

3-Formylchromone 1a condensed with alkyl acetoacetate or its acid in the presence of ammonia to give the pyridine derivatives 77 (46-50\%). While, aldehyde 1a condensed with acetoacetamide to produce the 2-pyridone derivative $\mathbf{7 8}$ (Scheme 37). The reaction involves ring opening of pyrone moiety at $\mathrm{C}_{2}$ [62-64].

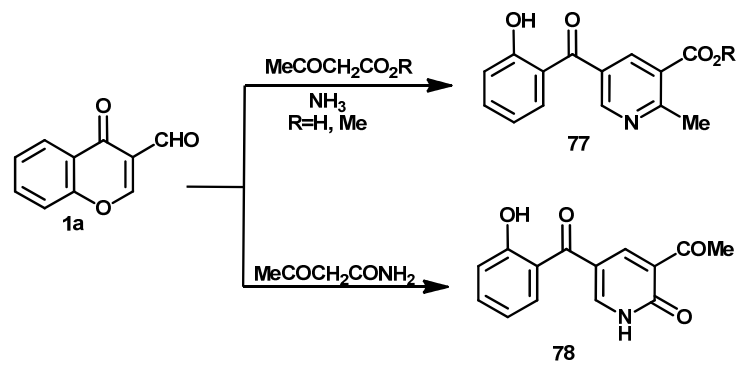

Scheme 37

When 3-formylchromones 1a-c,g were allowed to react with equimolar amounts of tosylmethyl isocyanide (TOSMIC) in THF in the presence of mild base as 1,8-diazabicyclo[5,4,0] undec7-ene (DBU) at room temperature, the 2-tosyl-5-(2hydroxybenzoyl)pyrroles $\mathbf{7 9}$ were isolated in good yields (Scheme 38) [65].

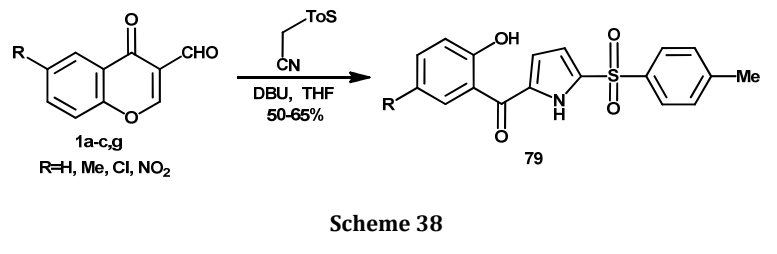

Condensation of 3-formylchromones 1a-d with $1 \mathrm{H}$ benzimidazole-2-acetonitrile $\mathbf{( 8 0 )}$ in ethanol at room temperature gave the carbonitrile derivative $\mathbf{8 1}$ in $96 \%$. When the reaction was carried out with in boiling ethylene glycol, 4cyano-2-(2-hydroxybenzoyl)pyrido[1,2-a]benzimidazoles $\mathbf{8 2}$ were obtainedin $70-81 \%$ yields (Scheme 39$)[66,67]$

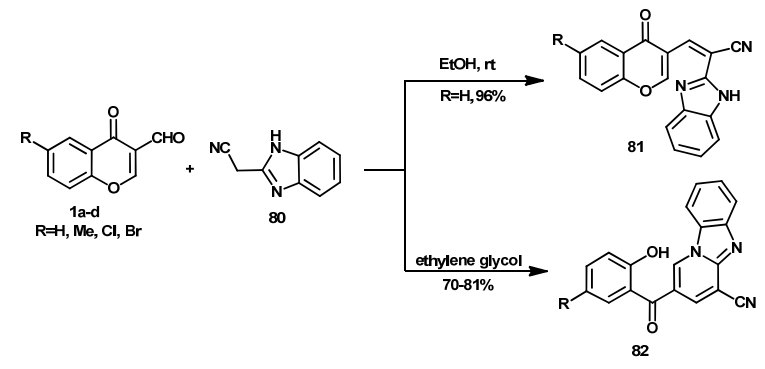

Scheme 39

Refluxing 1a with pyrazolinyltriazinylacetonitrile (83) in ethanol containing few drops of piperidine gave the condensation product $\mathbf{8 4}$ in $95 \%$ yield, as antitumor agent (Scheme 40) [68]

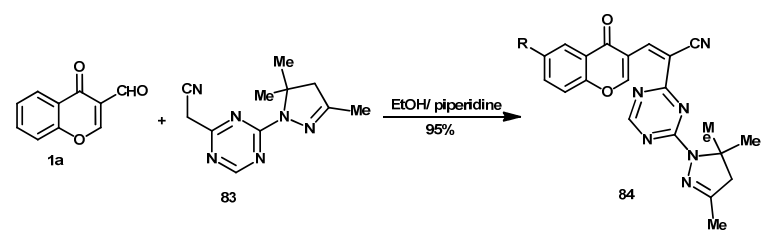

Scheme 40

Condensation of 1a with imidazole derivative 85 in $\mathrm{Me}_{3} \mathrm{SiCl} / \mathrm{DMF}$ produced the imidazo[1,2- $a$ ] pyridine 86 in $75 \%$ yield (Scheme 41) [69].

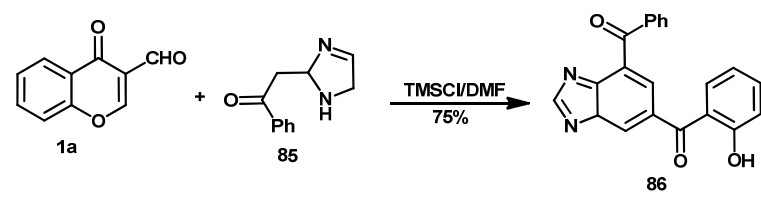

Scheme 41

Oxazolones $\mathbf{8 7}$ were readily obtained from the reaction of 3 -formylchromones 1a,b and $\mathrm{N}$-acetyl/ benzoylglycine in acetic anhydride containing freshly fused sodium acetate (Scheme 42) $[17,70,71]$.

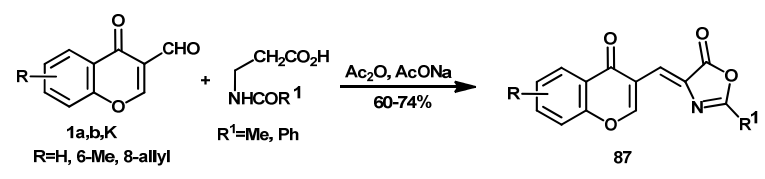

Scheme 42

On the other hand, the isoxazolone derivatives $\mathbf{8 8}$ were obtained in good yields (81-89\%) from the Knoevenagel condensation of 3-formylchromones 1a-d with 3-methyl (or 
phenyl)-5-isoxazolone in ethanol at room temperature (Scheme 43) [72].<smiles>[R]c1ccc2occ(C=O)c(=O)c2c1</smiles>

$1 a, d$ $\mathrm{R}=\mathrm{H}, \mathrm{Me}, \mathrm{Cl}, \mathrm{Br}$<smiles>[R]C1=NOC(=O)C1=Cc1coc2ccc([R])cc2c1=O</smiles>

Scheme 43

3-Formylchromone 1a reacted with hetarylmethylamines 89 in DMF under heating by molar ratio 1:1 in the presence of 4 molar equivalents of $\mathrm{Me}_{3} \mathrm{SiCl}$ (trimethylsilyl chloride) to give 5hetaryl-[1 $1 H$-pyrrol-3-yl](2-hydroxyphenyl)methanones 90 in $68-91 \%$ yields. When the reaction carried out in molar ratio 2:1 (3-formylchromone: amines), the fused chromonopyrrolyl chromones 91 were obtainedin 54-64\% yields (Scheme 44) [73].

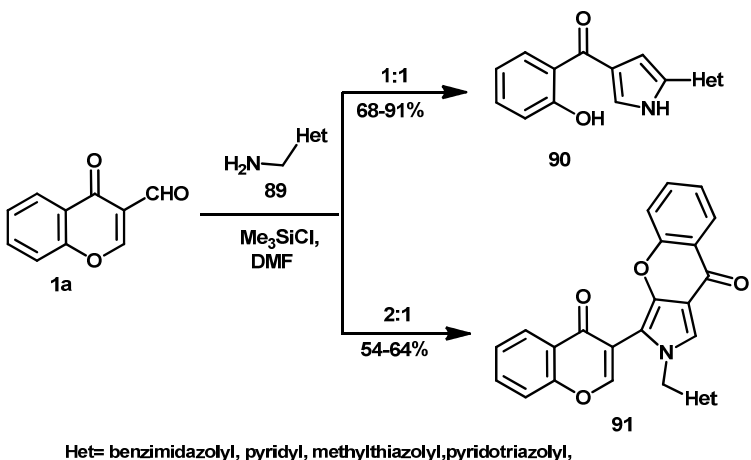

Het= benzimidazolyl, pyridyl, methylthiazolyl,pyridotriazolyl, benzothiazolyl, hydroxypyridyl, $N$-methylbenzimidazolyl, $\mathrm{N}$-methyltriazolyl

Scheme 44

Cyclocondensation of 3-formylchromone 1a with glycine derivatives 92 in the presence of $\mathrm{Me}_{3} \mathrm{SiCl}$ (4 equivalents) afforded pyrrole derivatives 93 in moderated yield (Scheme 45) [73].

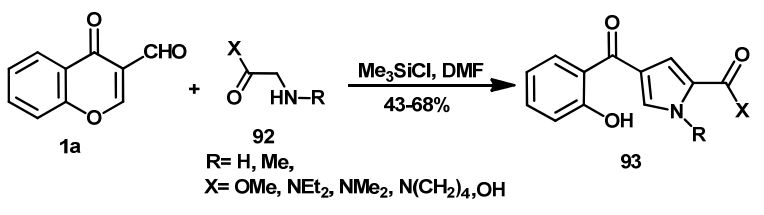

Scheme 45

A high yield of the novel pyrrolo[2,1- $a$ ] isoquinoline derivative 94 was prepared from the reaction of 3-formyl chromone 1a with isoquinoline and phenacyl bromide in aqueous medim containing DBU as a catalyst as reported by Naskar et al. (Scheme 46) [74].

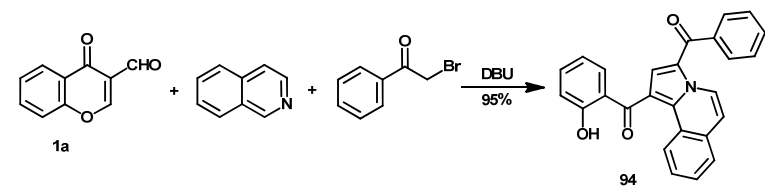

Scheme 46

Therefore, condensation of 3-formylchromones with acyclic active methylene compounds produced the corresponding condensation products or a variety of products depending on the reagent used and the reaction conditions.

\subsubsection{Condensation reactions with cyclic active methylene compounds}

Condensation of 3-formylchromones 1a-d,g with 1,3indandione $\mathbf{9 5}$ in glacial acetic acid containing piperidine afforded the condensation products 96 in $61-92 \%$ yields (Scheme 47) [75].

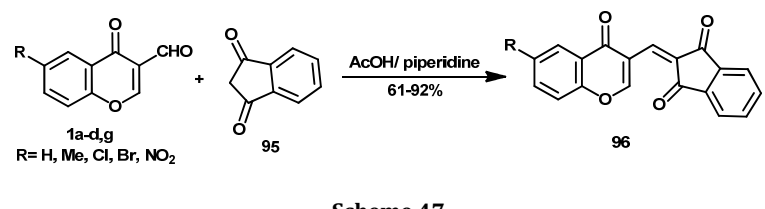

Scheme 47

Treatment of 3-formylchromone 1a with 3-oxo-2,3dihydrobenzo[b]thiophene-1,1-dioxide $\mathbf{9 7 a}$ and oxindole (indolone) $97 \mathbf{b}$ in dry pyridine afforded the corresponding condensation products 98 (Scheme 48) [76].

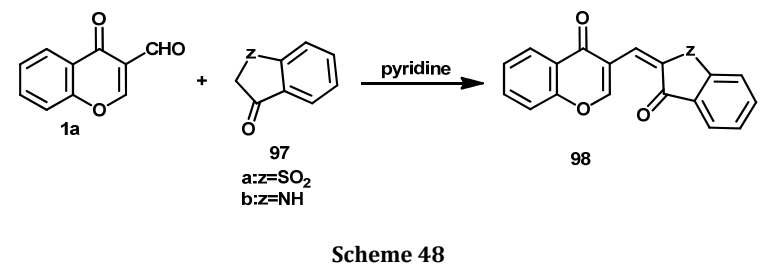

Simple condensation of aldehyde 1a with indolinone 99a,b in the presence of sodium bicarbonate under microwave irradiationyielded $(1 H)$-3-(4-oxo- $4 H$-chromen-3-yl) methylene] indolin-2-one (100a) and 1-[(2,6-dichlorophenyl)-3-(4-oxo4H-chromen-3-yl)methylene] indolin-2-one (100b), respectively (Scheme 49) [76,77].

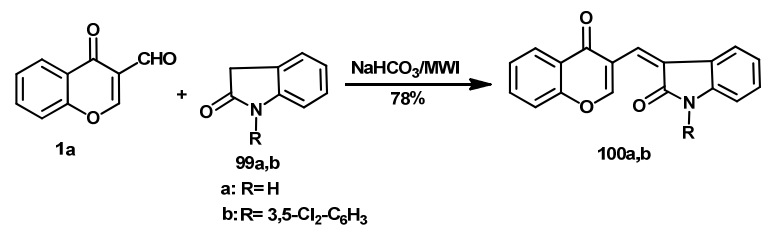

Scheme 49

Condensation reaction of $\mathbf{1 a}$ and pyrazolone derivatives 101a,b in 1:1 molar ratio, under classical method or microwave irradiation, afforded 1-aryl-3-methyl-4-(4-oxo-4Hchromen-3-yl)methylene]pyrazol-5(4H)-ones (102a,b), [77,78] while using 1:2 molar ratio afforded the new 1-(chromon-3-yl)1,1-bis(4-hydroxy-6-methyl-2-oxo-2H-pyran-3-yl)methane 103 (Scheme 50) [79].

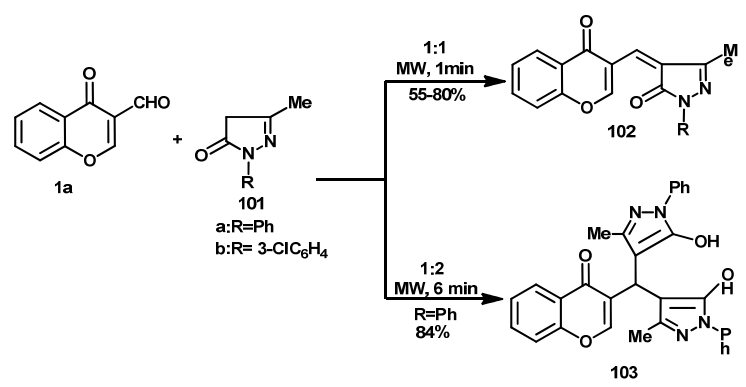

Scheme 50

Condensation of 3-formylchromone (1a) with 1phenylpyrazolidine-3,5-dione (104) in glacial acetic acid containing freshly fused sodium acetate, gave 4-[(4-oxo- $4 \mathrm{H}$ - 
chromen-3-yl)methylene]-1-phenyl-pyrazolidine-3,5-dione (105) (Scheme 51) [80].

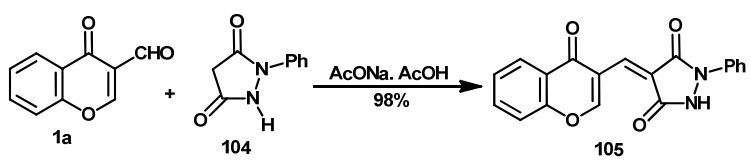

Scheme 51

Also, treatment of 3-formylchromones 1a-c,e with 3(trifluoromethyl)-1-phenyl-1H-pyrazol-5(4H)-one (106) in acetic acid yielded 3-(trifluoromethyl)-4-[(6-substituted 4-oxo4H-chromon-3-yl)methylene]-1-phenyl-1H-pyrazol-5(4H)-ones 107 in70\% yield (Scheme 52) [81].

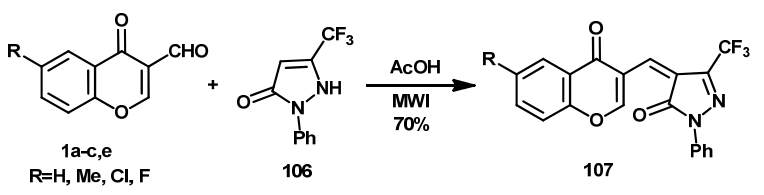

Scheme 52

Condensation of 1a with pyrazolinone 108a and isoxazolinone $\mathbf{1 0 8 b}$ in acetic acid containing fused sodium acetate gave 5\{4-[(4-oxo- $4 H$-chromen-3-yl)methylene-5-oxo4,5-dihydro-1H-pyrazol-3-yl)]\}-1-phenylpyrazolo[3,4-d] pyrimidin-4-one 109a and 5-\{4-[(4-oxo-4H-chromen-3yl)methylene-5-oxo-4,5-dihydroisoxazol-3-yl)]\}-1-phenyl pyrazolo $[3,4-d]$ pyrimidin-4-one $\mathbf{1 0 9 b}$, respectively (Scheme 53) [59].

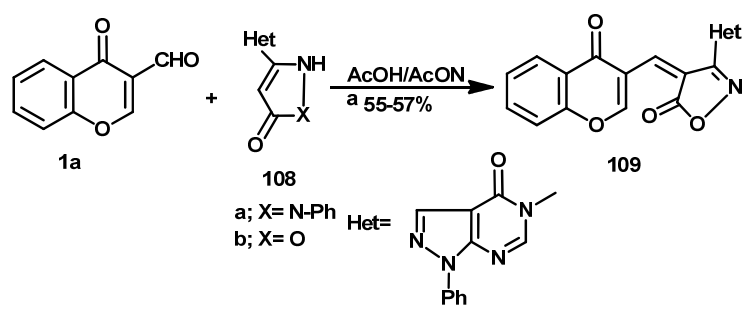

Scheme 53

Similarly, condensation of 3-formylchromone (1a) with pyrazol-3-ylquinoline derivative $\mathbf{1 1 0}$ in glacial acetic acid containing sodium acetate afforded chromenylpyrazolinone 111 (Scheme 54) [82].

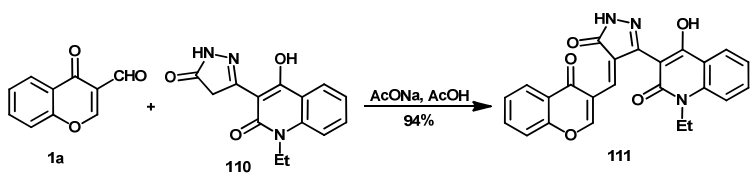

Scheme 54

Also, condensation of 1a-d,f,g with creatinine $\mathbf{1 1 2}$ in DMSO using boric acid as a catalyst yielded 2-imino-1-methyl-5-(6substituted 4-oxo-4H-chromen-3-yl)methylidene]imidazolin-4one (113). While, 2-acetamido-1-methyl-5-[(6-substituted 4oxo-chromen-3-yl)methylidene]-4,5-dihydroimidazol-4-one 114 was obtained when the reaction took place in acetic anhydride and potassium acetate (Scheme 55) [83].

3-Formylchromones 1a-d,f,g condensed with thiohydantion 115 in acetic anhydride in the presence of potassium acetate under both irradiation and classical condition yielded 2-thioxo-5-[(6-substituted-4-oxo-chromen-3yl)methylidene]imidazolidine-4-ones (116) (Scheme 56) [83].

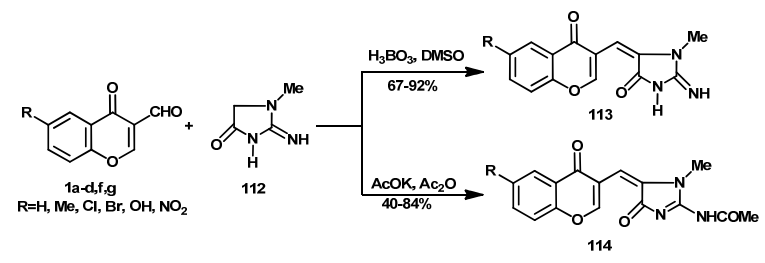

Scheme 55

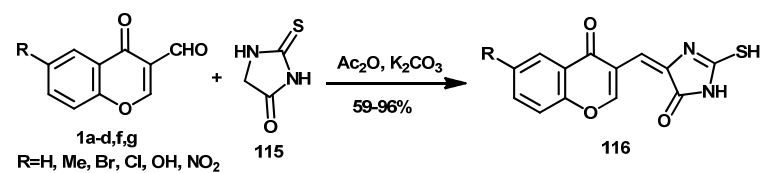

Scheme 56

Chromonyl-2,4-thiazolidinediones $\mathbf{1 1 8}$ were prepared by the Knoevenagel condensation of 2,4-TZDs (2,4-thiazolidine diones) 117 with 3 -formylchromones 1a,b,n in glacial acetic acid containing freshly fused sodium acetate (Scheme 57) [8486].

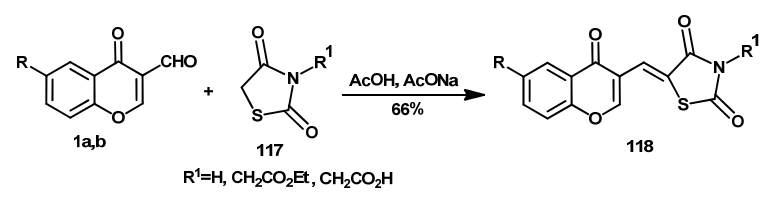

Scheme 57

Similarly, condensation of 3-formylchromone 1a-d,f,g with 3-ethylrhodanine 119 in acetic anhydride/potassium acetate under both irradiation and classical condition, gave 2-thioxo-5[(6-substituted-4-oxo-4H-chromen-3-yl)methylidene] thiazolidin-4-ones 120 (Scheme 58) [83].

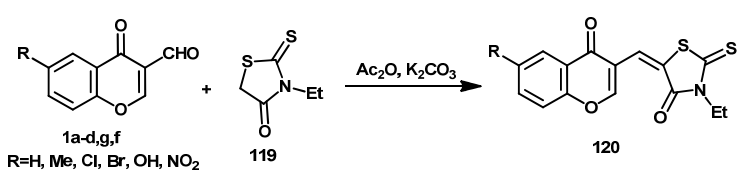

Scheme 58

Condensation of carboxaldehyde 1f with ethyl 2-cyano-2(3-phenyl-5-oxo-1,3-thiazolan-2-ylidene) acetate (121) gave the corresponding arylidene derivative 122 (Scheme 59) [61].

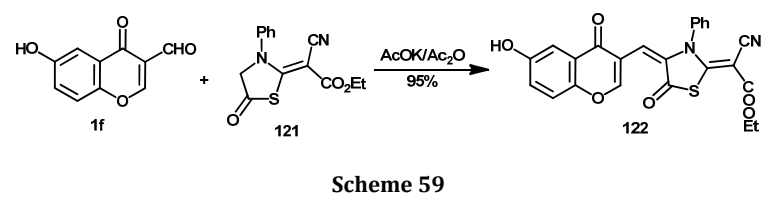

Reaction of 3-formylchromone (1a) with [1,3]thiazolo[3,2a] benzimidazol-3 $(2 H)$-one (123) in glacial acetic acid containing fused sodium acetate afforded the condensation product $\mathbf{1 2 4}$ in high yield (60-97\%) [87].Similarly, treating 1a with 2-methyl[1,3]thiazolo[1,2,4]triazol-5(6H)-one (125) in acetic anhydride/sodium acetate yielded the condensation product 126 in 68-91\% yields (Scheme 60) [88].

Knoevenagel products $\mathbf{1 2 8}$ were obtained in low yields (15-43\%) by heating 3-formylchromones 1a-c with $2 H-1,4-$ benzothiazin-3(4H)-one (127) in acetic anhydride/potassium acetate medium for 6-10 h. Using microwave the yields were increased (33-62\%) in short time (7-20 min) (Scheme 61) [87]. 


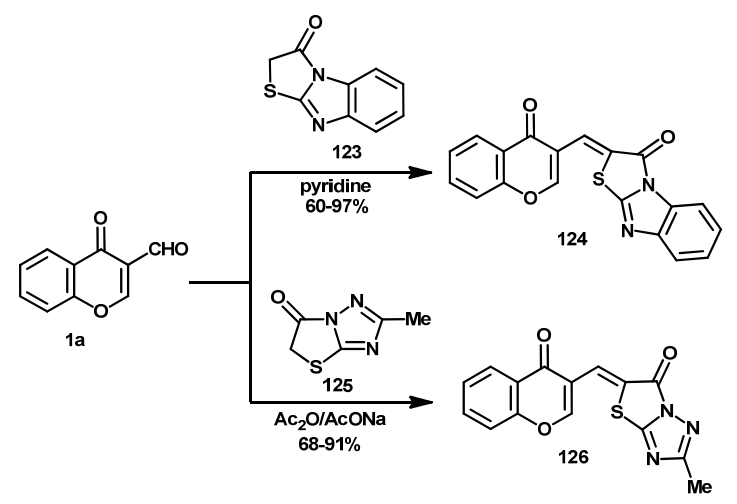

Scheme 60

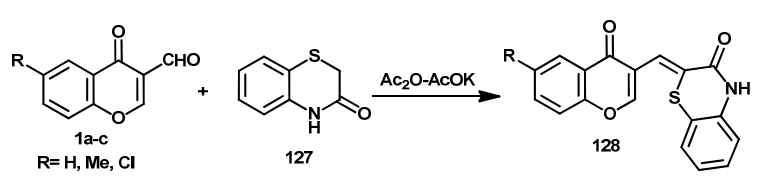

Scheme 61

Reaction of 6-bromo-3-formylchromone 1d with 2-aryl-4hyrdoxy-6H-1,3-thiazin-6-ones 129a,b in DMSO or pyridine gave 8-bromo-3,10-dioxo- $N$-(arylcarbonothioyl)-4,4a-dihydro$3 \mathrm{H}, 10 \mathrm{H}$-pyrano[4,3- $b]$-chromene-4-carboxamides $(\mathbf{1 3 0 a}, \mathbf{b})$ in $60-70 \%$ yields (Scheme 62) [89].

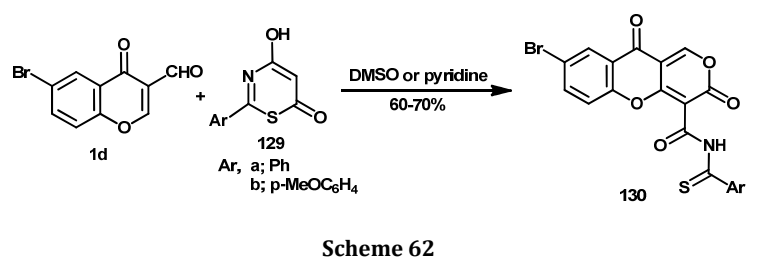

Also, condensation of 3-formylchromone 1a with dimedone (5,5-dimethylcyclohexane-1,3-dione) in acetic anhydride containing sodium acetate yielded the condensation products 131 in 54-64\% [87]. When the reaction took place in aqueous ethanol containing pyridine or aqueous pyridine by molar ratio (1:2) afforded the adduct $\mathbf{1 3 2}$ which dehydrated to formxanthone 133 in 73\% yield (Scheme 63) [60,76,90].

Meldrum's acid (2,2-dimethyl-1,3-dioxane-4,6-dione) undergoes Knoevenagel condensation with 3-formylchromone 1a-c,e producing the corresponding condensation product derivatives 134 in 90-95\% yields (Scheme 64) [91-93].

Reaction of 3-formylchromones 1a,c with 4-chromanone 135 in ethanol containing triethylamine gave benzopyrano-2,3dihydrobenzopyranones 136 in $67-80 \%$ yields (Scheme 65) [94].

Treatment of 3-formylchromone (1a) with barbituric acid 137a, thiobarbituric acids $137 \mathbf{b}$ and 1,3-dimethylbarbituric acid 138 gave 5-[(4-oxo-4H-chromen-3-yl)methylene] pyrimidine derivatives 139 and 140,respectively (Scheme 66) [76,77].

$\mathrm{N}$-Methylpyrrole reacted with 3-formylchromones 1a,c,d,g under solvent-free conditions exclusively via 1,4-addition followed by recyclization to form 2-hydroxy-3-(1-methylpyrrol-2-ylmethylene)chroman-4-ones $\mathbf{1 4 1}$ in good yield (Scheme 67) [95].

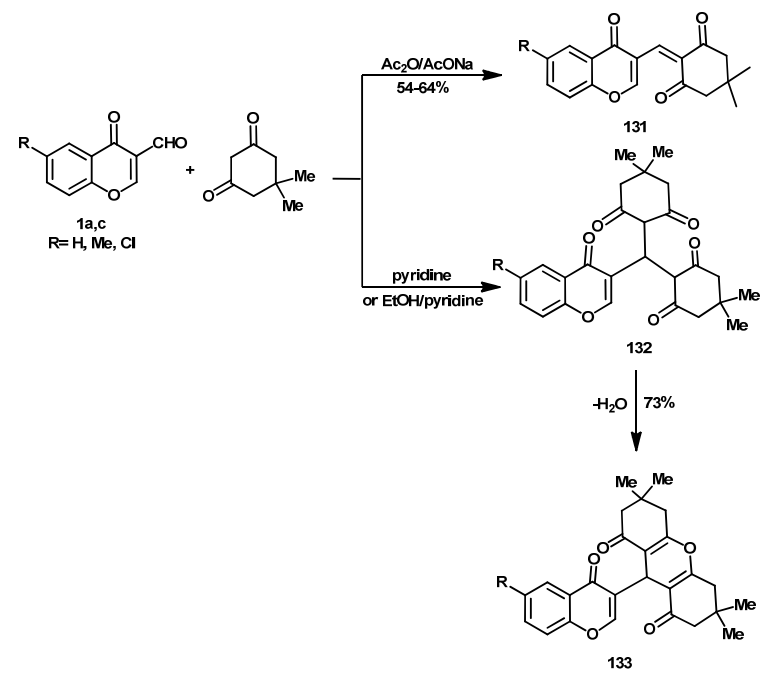

Scheme 63
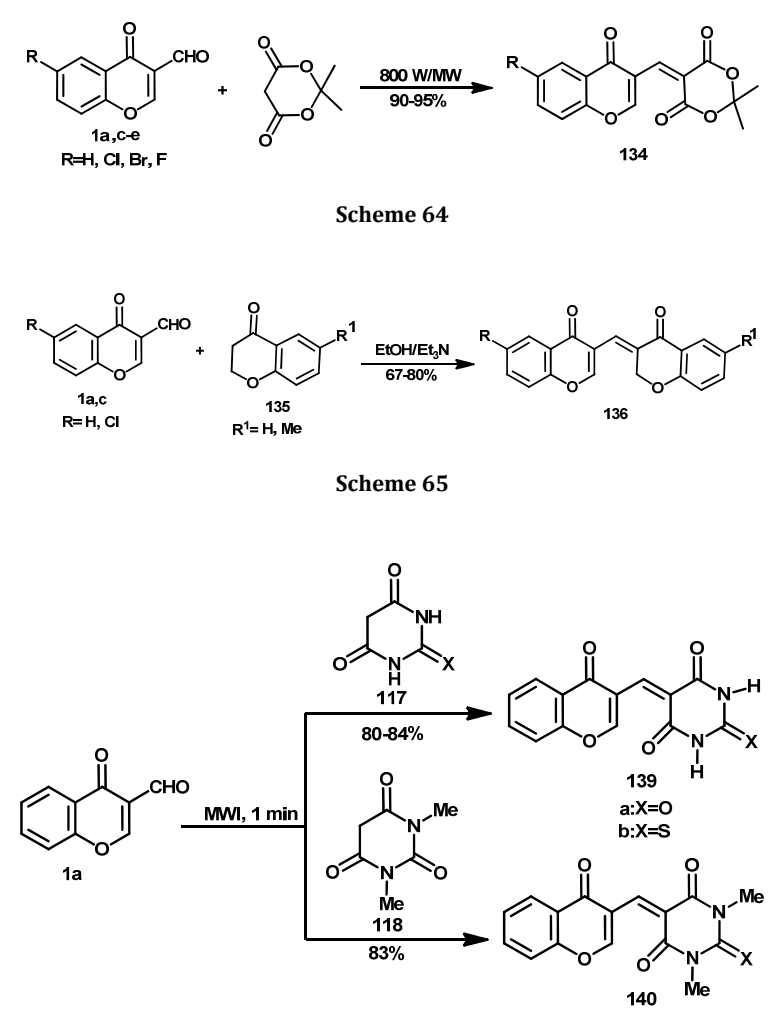

Scheme 66

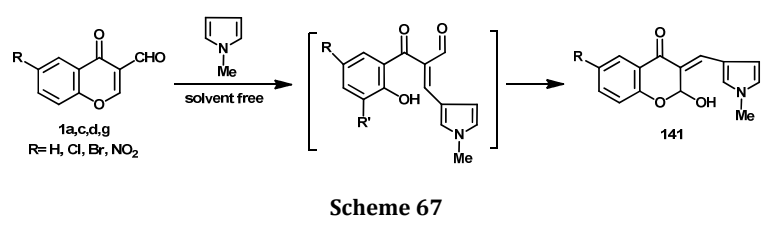

A similar reaction of 6,8-dibromo-3-formylchromone (1r) with indole proceeded exclusively via 1,4-addition followed by recyclization to form a mixture of $E$-isomer 142 (91\%) and $Z$ isomer 142 (9\%) (Scheme 68) [95]. 


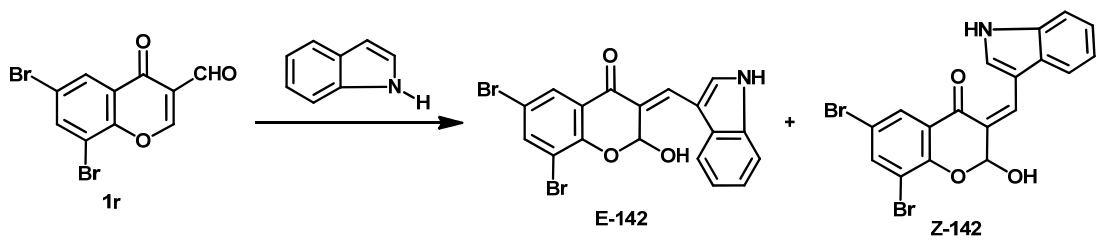

Scheme 68

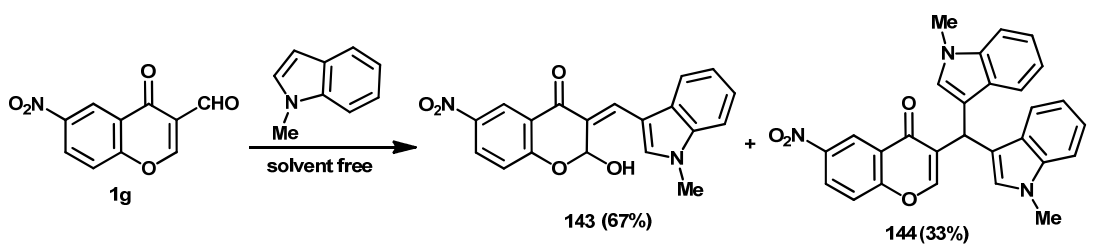

Scheme 69

Reaction of 3-formyl-6-nitrochromone (1g) with $\mathrm{N}$ methylindole afforded a mixture of E-(2-hydroxy-6-nitro-3-(1methyindol-3-ylmethylene)chroman-4-one (143)and the bisadduct 144 (Scheme 69) [95].

On the other hand, 3-formylchromones $\mathbf{1 a - c , g , j}$ reacted without solvent with excess indole, 1-methyl or 2methylindoles (2 equivalents) to give (chromon-3-yl)-bis(indol-3-yl)methanes 145 (Scheme 70) [95].

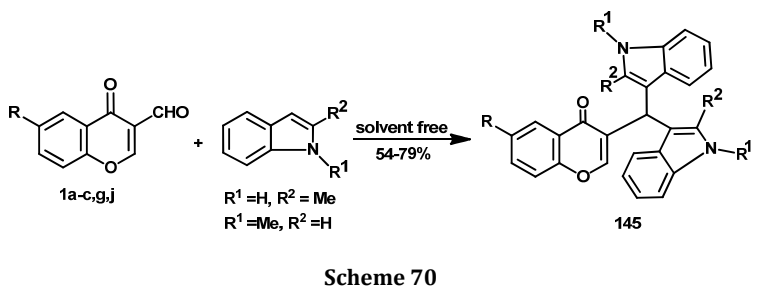

Also, 3-formylchromones $\mathbf{1 a}$ reacted with triacetic acid lactone and 4-hydroxycoumarin derivatives (2 equivalents), under conventional and solvent free methods, to give (chromon-3-yl)-bis-(hetaryl)methanes 146 and 147, respectively (Scheme 71) [79].

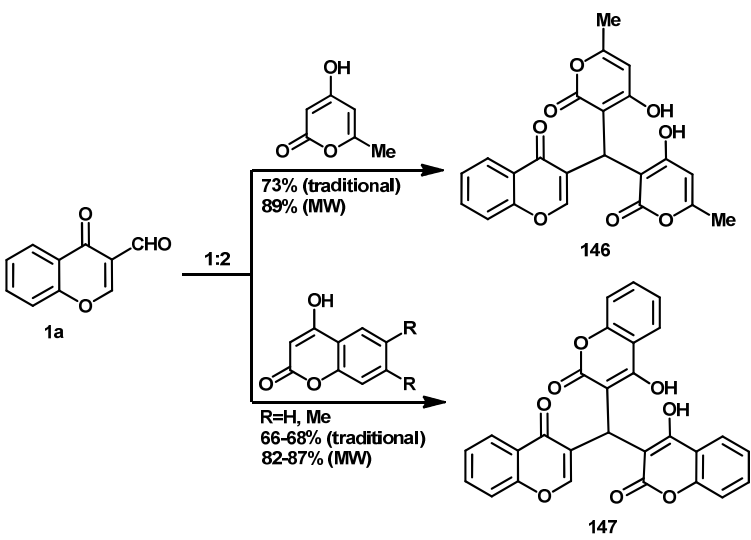

Scheme 71

Condensation of 3-formylchromones 1a,b with alkyl isocyanides in dry dichloromethane at room temperature afforded (1Z)-3-(alkylimino)-1-[(chromon-3-yl)methylene]1,3-dihydro-9H-furo [3,4-b]chromen-9-ones 148 in good yields (77-90\%) (Scheme 72) [96].
The reaction of 3-formylchromone $\mathbf{1 a}$ with 3,4dihydroquinoxalin-2(1H)-ones gave 2-(2-hydroxy-benzoyl) pyrrolo[1,2-a]quinoxalin-4(5H)-ones 149in 52-58\% yields, respectively (Scheme 73) [73].

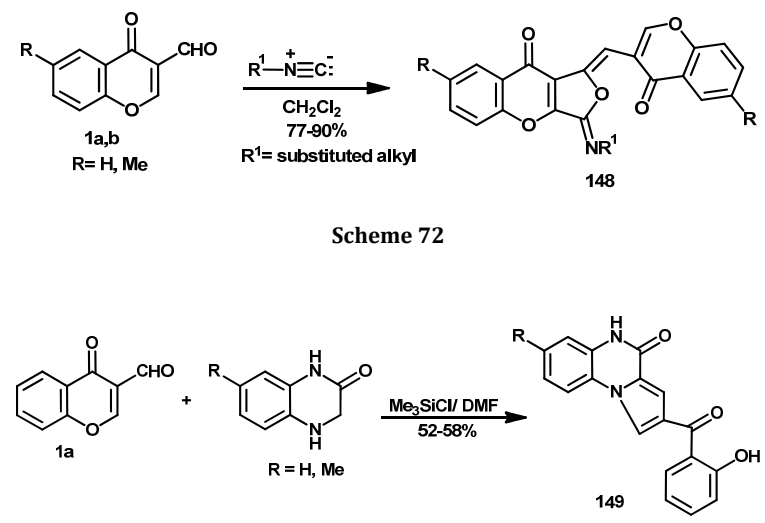

Scheme 73

Under acidic conditions, $p$-cresol underwent 1,2-addition through $\mathrm{C}-2$ atom to thealdehyde function of 3-formyl chromone (1a) to produce intermediate $\mathbf{1 5 0}$ which, converted to 2,14-dimethyl-10a $H, 15 \mathrm{a} H$-tribenzo[ $[b, e, i][1,6,7]$ trioxaphenalene (151) (Scheme 74) [97].

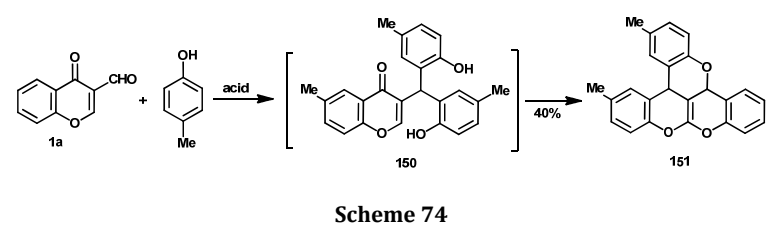

Treating carboxaldehyde 1a with $\beta$-ketoacid 152, [98] in glacial acetic acid containing freshly fused sodium acetate, yielded the Knoevenagel condensation products 153 which underwent dehydration by stirring in concentrated $\mathrm{H}_{2} \mathrm{SO}_{4}$ at room temperature to afford 3-chromonylmethylenepyrano[3,2c]quinoline derivatives 154. Moreover, compound 153 was obtained authentically from condensation reaction of pyrano [3,2-c] quinoline $\mathbf{1 5 5}$ with 1a (Scheme 75) [99]. 
<smiles>CC(C)n1c(=O)c(C(=O)CC(=O)O)c(O)c2ccc(C=O)cc21</smiles><smiles>CCn1c(=O)c(C(=O)/C(=C/c2coc3ccccc3c2=O)C(=O)O)c(O)c2ccccc21</smiles><smiles>CCN1C(=O)C2=C(Oc3c(c(=O)n(CC)c4ccccc34)C1=O)C(=O)C(=O)C(=Cc1coc3ccccc3c1=O)C2=O</smiles>

Scheme 75

Thus, a large number of chromone derivatives linked a variety of heterocyclic systems were prepared from the direct condensation of 3-formylchromones with heterocyclic compounds containing active methylene groups.

\subsection{Chemical reactivity of 3-formylchromones towards nitrogen nucleophiles}

\subsubsection{Reactions with primary amines}

A large group of 3-(aryl/heteroaryliminomethyl)chromone derivatives 156 were prepared from condensation reactions of 3-formylchromones 1a-d with a variety of aryl/hetarylaminesin non polar solvents such as benzene, toluene or xylene under reflux, in the presence of $p$-toluenesulfonic acid as a catalyst (Scheme 76) [100-108].

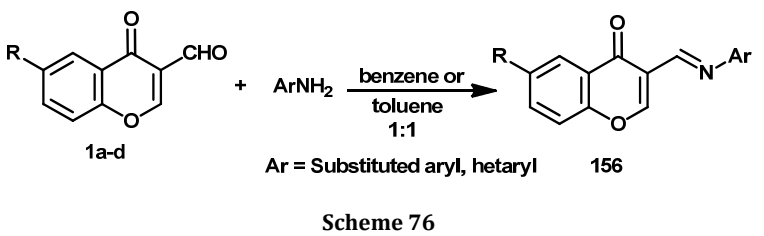

On the other hand, reaction of 3-formylchromones 1a-c with equimolar ratio of aryl/hetarylamines 157 in boiling ethanol gave 3-(aryl/hetarylaminomethylene)-2-(ethoxy) chromones 158, but when the reaction took place with two moles of $\mathbf{1 5 7}$ in dry toluene, the 1,4-adducts $\mathbf{1 5 9}$ were obtained (Scheme 77) [105-115].

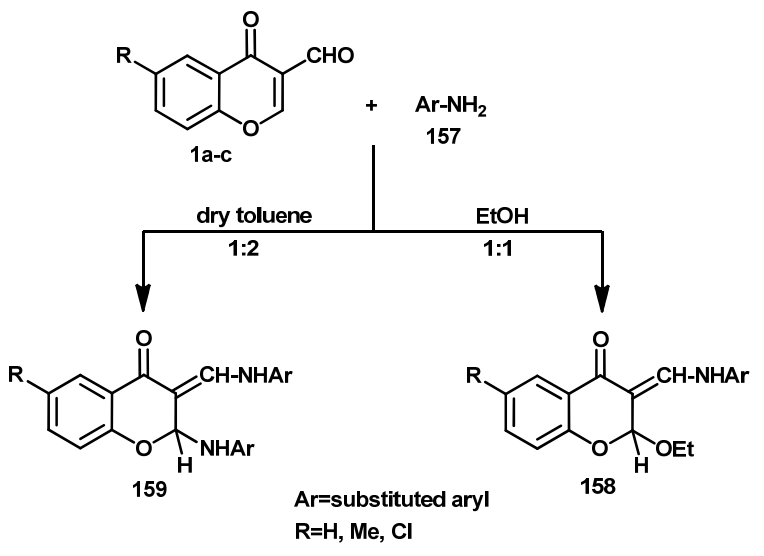

Scheme 77

Reaction of 3-formylchromone 1a with various anilines in the presence of $\mathrm{Me}_{3} \mathrm{SiCl} / \mathrm{DMF}$ led to either 3-(2hydroxybenzoyl)quinolines $\mathbf{1 6 0}$ or $7 \mathrm{H}$-chromeno[3,2c]quinolin-7-ones 161 (Scheme 78), depending on the structure of the starting aniline. Substituents in the aniline molecule that withdraw electrons favored the formation of 161; on the contrary, electron-rich anilines gave only 160 $[116,117]$

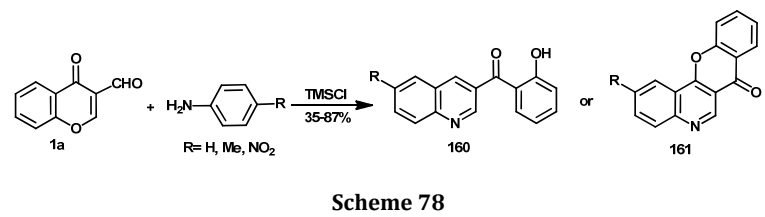

Condensation of 3-formylchromone (1a) with aniline and 6-amino-1,4-benzoxodioxane in methanol gave 3-(aniline methylene)-2-methoxychroman-4-one (162) and 3-(1,4benzodioxane-6-aminomethylene)-2-methoxychroman-4-one (163), respectively (Scheme 79) [118].

Also, reaction of 6-substituted 3-formylchromone 1a-c,j with aromatic amino carboxylic acid $\mathbf{1 6 4}$ in benzene or toluene yielded only 3-(arylaminomethylene)-2-hydroxychromon-4ones 165 at room temperature or under reflux (Scheme 80) [113].

Treatment of 3-formylchromone 1a with ethyl 2-aminopropanoate yielded pyrrole derivative 166 in high yield (Scheme 81) [119].

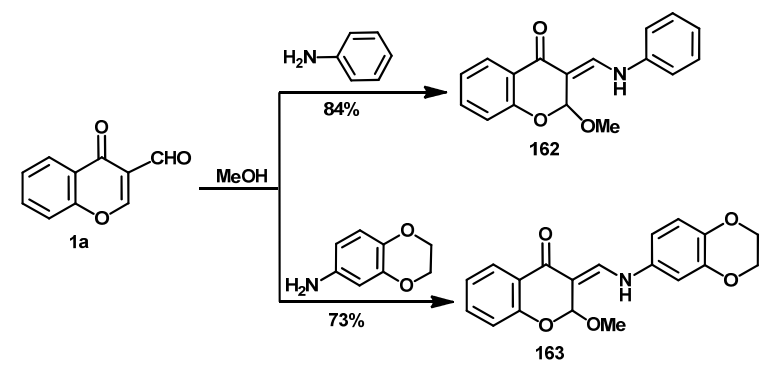

Scheme 79

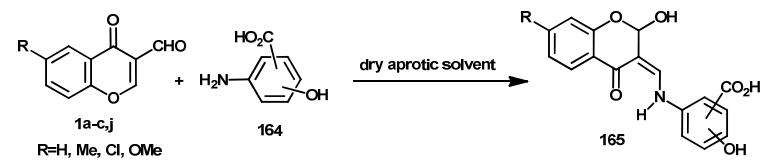

Scheme 80

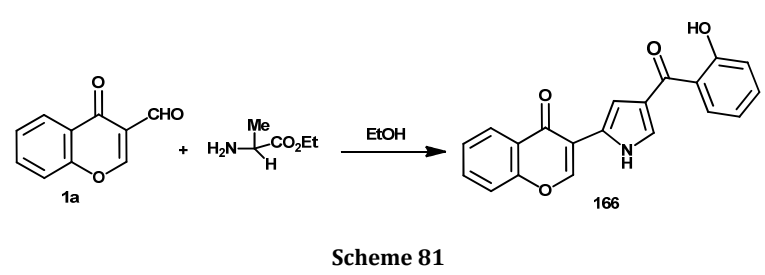

Chromenopyridines 168 were prepared by treating 3formylchromone 1a with enaminonitriles, enaminoketones or $\beta$-aminoesters 167 (Scheme 82) [63,64,76,120].

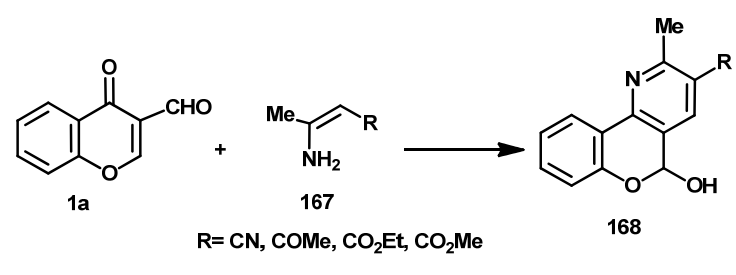

Scheme 82 


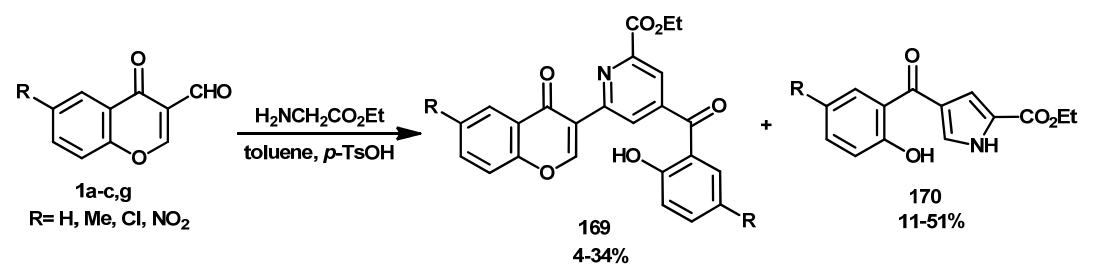

Scheme 83

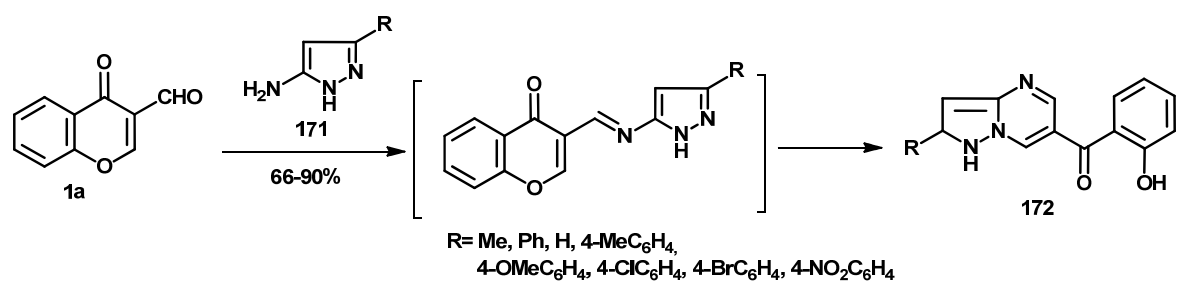

Scheme 84

Interaction of 3-formylchromones 1a-c,g with ethyl glycinate in boiling toluene in the presence of $p$-toluenesulfonic acid gave a mixture of ethyl 4-(2-hydroxybenzoyl)-6-(4-oxochromen-3-yl)-pyridine-2-carboxylates 169 and ethyl 4-(2hydroxybenzoyl)pyrrole-2-carboxylates $\mathbf{1 7 0}$ (Scheme 83) $[62,65,76,121]$.

Also, the reaction of 3 -formylchromone (1a) with equimolar amount of aminopyrazoles $\mathbf{1 7 1}$ in absolute ethanol afforded 6-(2-hydroxybenzoyl)pyrazolo[1,5-a]pyrimidines 172, via iminomethyl derivative (Scheme 84) [122].

Treatment of 3-formylchromones 1a,b,e with 5-amino pyrazoles 173 in boiling ethanol containing $p$-toluenesulfonic acid gave 2-hydroxybenzoylpyrazolo[3,4-b]pyridines 174. While, when this reaction was carried out at lower temperature $\left(-10{ }^{\circ} \mathrm{C}\right)$, the enamine-adducts $\mathbf{1 7 5}$ were isolated. Enamineadducts rearrange into pyrazolo[3,4- $b]$ pyridines 174 after prolonged refluxing (Scheme 85) [123].

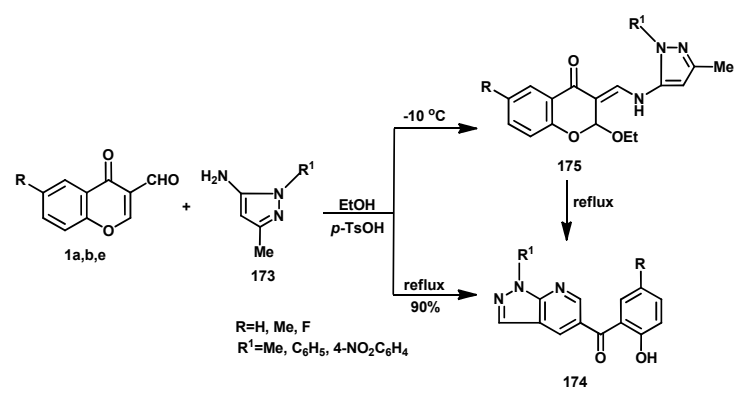

Scheme 85

Reaction of 3-formylchromone $\mathbf{1 a}$ with ethyl 2aminopyrimidine carboxylates 176 in ethanol gave ethyl 7-(2hydroxybenzoyl)-2 $H$ - $(4 H)$ pyrimido[1,2-a] pyrimidine-3carboxylate 177 (Scheme 86) [124].

On the other hand, aminopyrimidones 178 reacted with aldehyde $1 \mathrm{a}$ in refluxing ethanol to afford the unexpected pyrido[2,3- $d$ ]pyrimidines $\mathbf{1 7 9}$ but not the predicted pyridopyrimidines 180 (Scheme 87) [125].

Acetic acid catalyzed condensation of aldehyde 1a with 1(2-aminophenyl)pyrrole (181) led to the pyrrolo[1,2-a] quinoxaline derivative 182 (Scheme 88) [126].

2-(4H-4-Chromen-3-yl)-3-aryl-1,2-dihydroquinazolin$4(3 H)$-ones 184 are the final products from the reaction of carboxaldehyde 1a and amino amides 183 in both ethanolic and nonpolar medium (Scheme 89) [127].

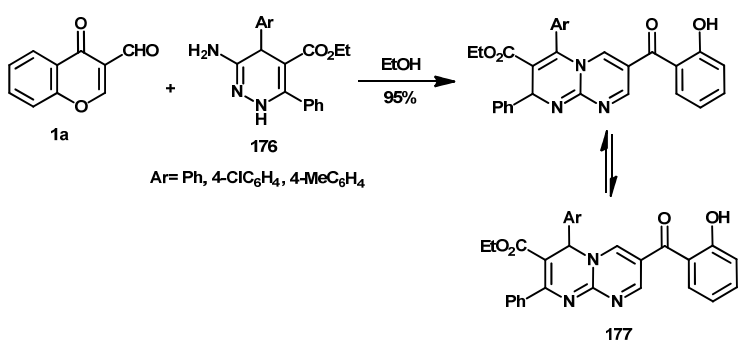

Scheme 86

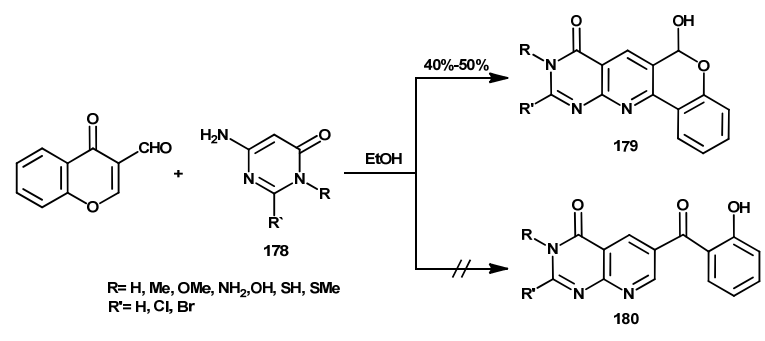

Scheme 87

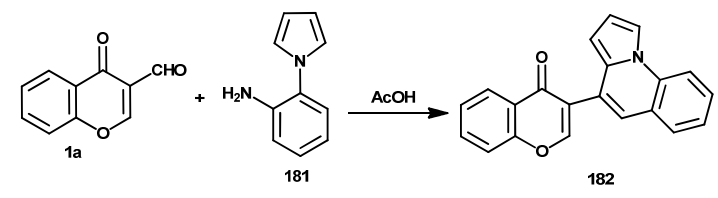

Scheme 88

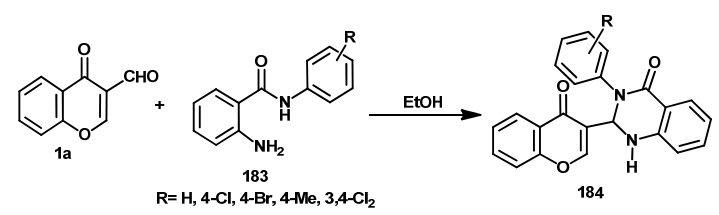

Scheme 89 


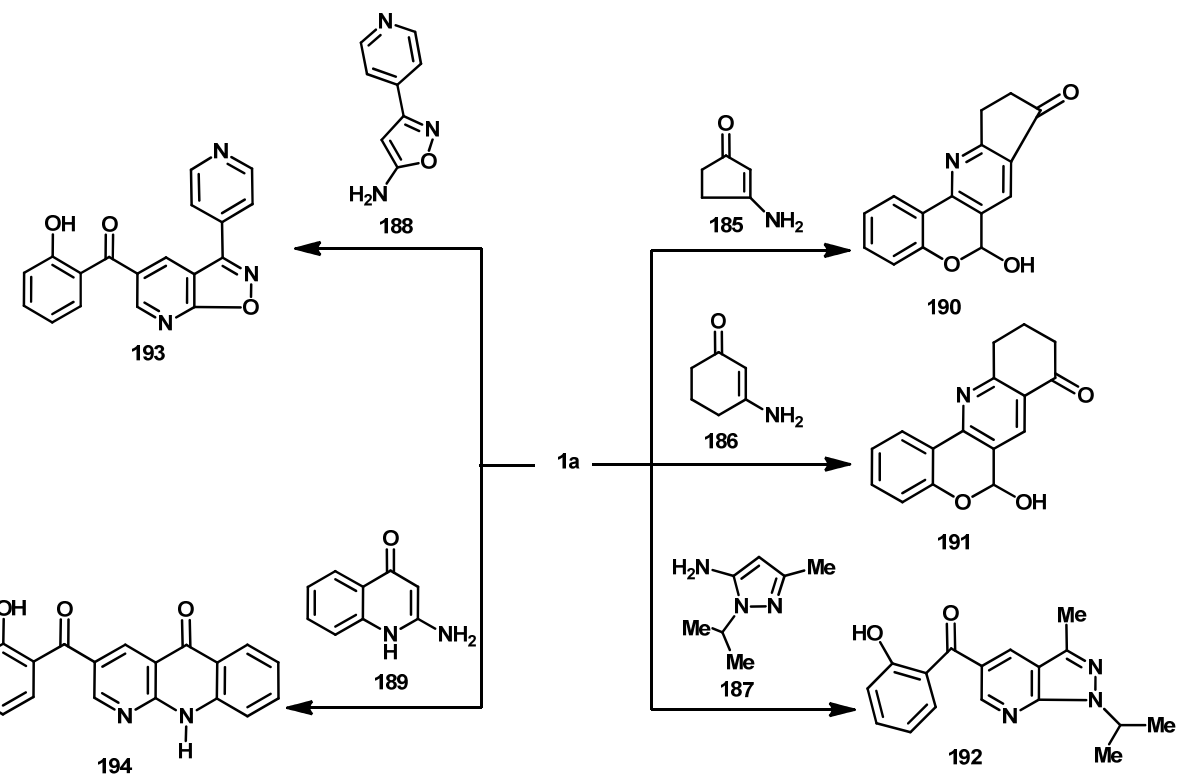

Scheme 90

Reaction of 3-formylchromone 1 a with enamine derivatives 185-189 in pyridine or glacial acetic acid led to fused pyridine derivatives 190-194 in one step, respectively (46-82\% yields) (Scheme 90) [76].

Reaction of 3-formylchromone 1a with 4-amino-3mercapto-5-phenyl-1,2,4-triazole (195) under phase transfer condition yielded ring-opened thiadiazepine 196 (Scheme 91) [128].

Condensation of 1a-c with 4-phenyl-1H-imidazole-1amines 197 in the presence of $\mathrm{Me}_{3} \mathrm{SiCl} / \mathrm{DMF}$ gave imidazo[1,5b]pyridazines 198 in 81-96\% yields (Scheme 92) [129].<smiles>Nn1c(S)nnc1-c1ccccc1</smiles>

Scheme 91

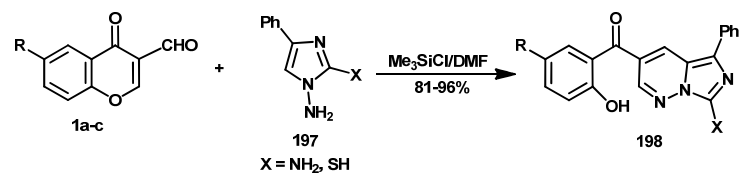

Scheme 92

Diaminomethane reacted with 3-formylchromone $\mathbf{1 a}$ to yield pyrimidine derivative 199. The reaction initially takes place on the formyl group and is followed by an intramolecular attack of the second amine function on the $\mathrm{C}-2$ atom of the pyrone ring followed by the ring opening (Scheme 93) [130].

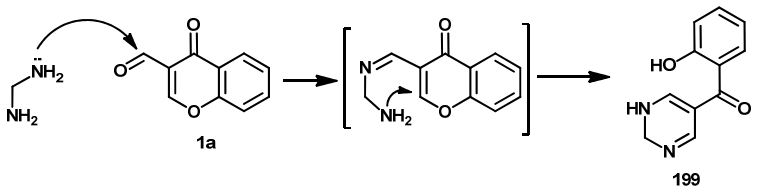

Scheme 93
Condensation of equimolar amountsof 1a-c with ethylenediamine in benzene gave the 1,2-bis[(chromon-3yl)methyleneamino]ethane 200, using excess of ethylenediamine afforded poor yield of $1: 1$ condensation product (Scheme 94) [130].

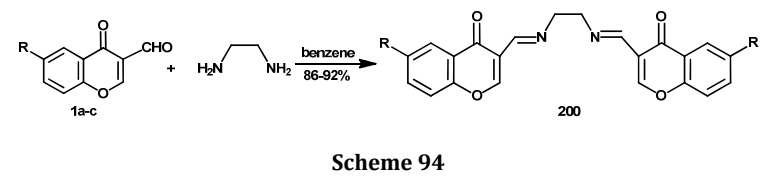

Reaction of aldehyde $\mathbf{1 a}$ with $o$-phenylenediamine in boiling ethanol gave 7,16-bis(2-hydroxybenzoyl)-5,14dihydrodibenzo[b-i $][1,4,8,11]$ tetraazacyclotetradecine (201), which then oxidized to 3-(2-benzimidazolyl)chromone 202, while in boiling benzene, benzodiazepino chromone 204 was obtained during dehydrogenation ofthe initially formed dihydro analogous 203, through air oxidation or boiling in nitrobenzene (Scheme 95) [130-141].

On the other hand, cyclocondensation of 6-chloro-3formylchromone (1c) with diaminopyridone derivative 205 in DMF under reflux containing few drops of piperidine afforded the 1,2,3,5-tetrahydro[1,2,4] triazolo[1,5-a]pyridine derivative 206 (Scheme 96) [142].

Condensation reaction of 6-chloro-3-formylchromone (1c) with $p$-phenylenediamine in dry benzene containing $p$ toluenesulfonic acid in $1: 1$ and $2: 1$ molar ratio gave 3 -[(4aminophenylimino)methyl]-6-chloro-4-oxo-4H-chromene (207) and the bis compound 208, respectively (Scheme 97) [143].

On the other hand, condensation reaction of 3-formyl chromone (1a) with 2-aminophenol and 2-aminothiophenol in ethanol afforded compound $\mathbf{2 0 9}$ via the formation of the simple condensation product followed by 1,4-addition of ethanol molecules (Scheme 98) [132].

Consequently, the products obtained from the reaction of 3formylchromones with primary amines depend mainly on the type of amine, molar ratio and the solvent used. Also, a diverse number of heterocyclic systems were obtained from the condensation of 3 -formylchromones with bifunctional nucleophiles. 


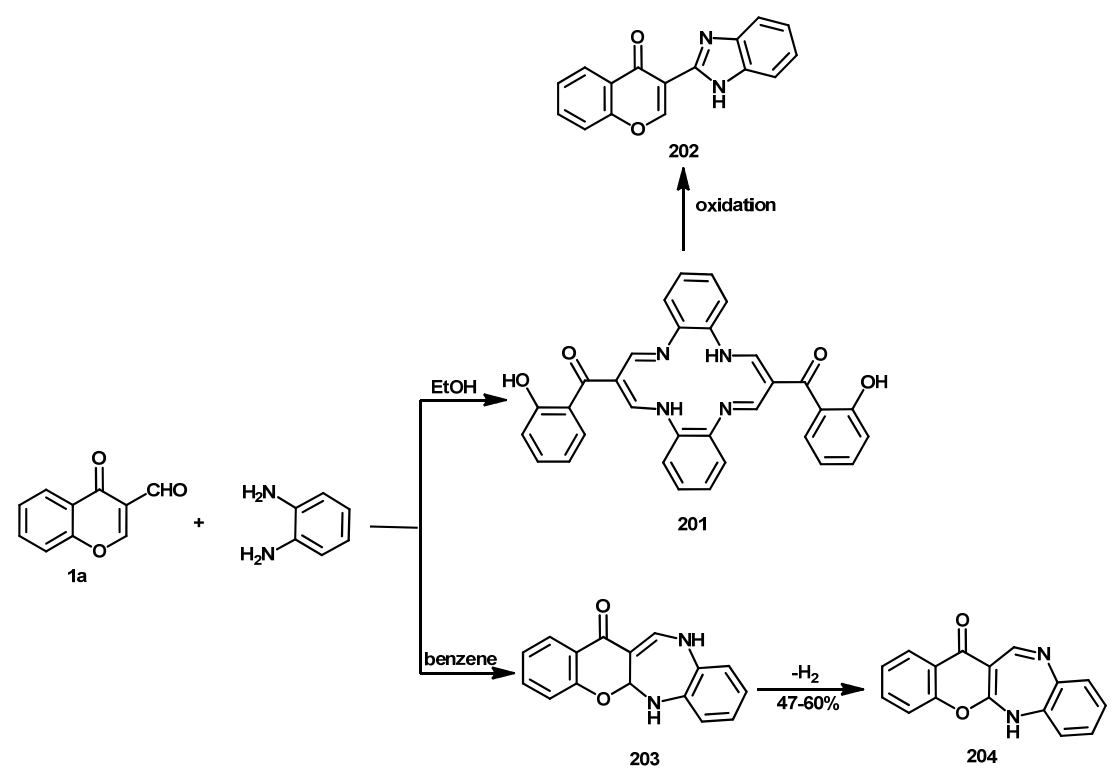

Scheme 95<smiles>Cc1c(-c2coc3ccc(Cl)cc3c2=O)c(C#N)c2n(c1=O)CNC2c1coc2ccc(Cl)cc2c1=O</smiles>

Scheme 96

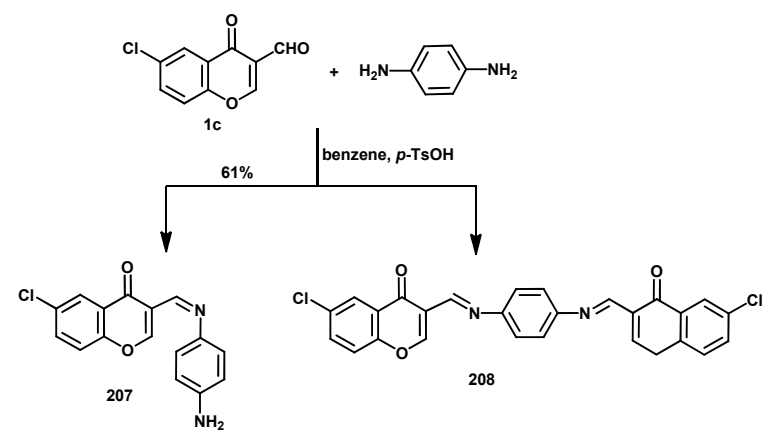

Scheme 97

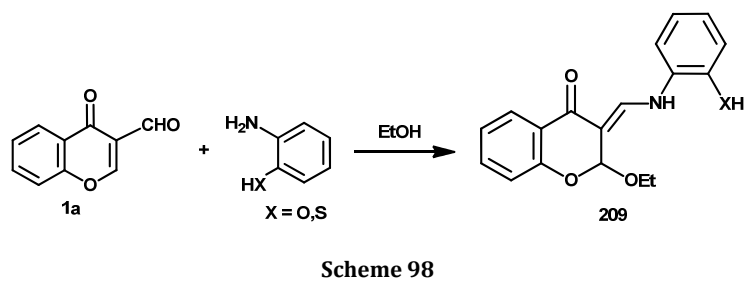

\subsubsection{Reactions with secondary amines}

When 3-formylchromone 1a treated with secondary amine like piperidine, an unstable 1,4-adduct $\mathbf{2 1 0}$ is formed, this adduct undergoes base catalyst deformylation to give the enaminoketone $\mathbf{2 1 1}$ in 55\% yield [151]. Further, 3formylchromones $\mathbf{1 a}$ when heated with $N$-methylpiperazine in ethanol furnished 1-(2-hydroxyphenyl)-3-(4-methylpiperazin1-yl)propenone (212) [41].Similarly, 1-(2-hydroxyaryl)-3(pyrrolidin-1-yl)prop-2-en-1-one (213) was synthesized by the reaction of 3-formlylchromones 1a with pyrrolidine in dry ethanol (Scheme 99) [145,146].
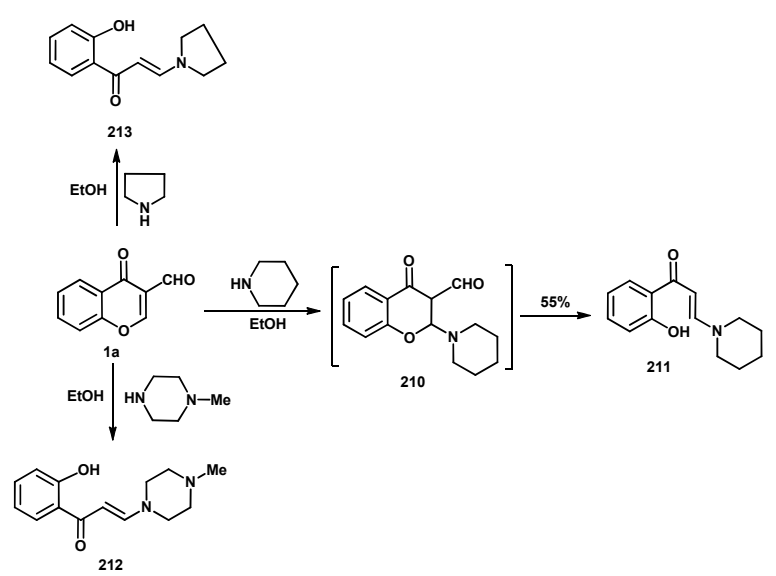

210

Scheme 99

Treatment of 3-formylchromone (1a) with $N$-methylglycine in boiling toluene in the presence of $p$-toluenesulfonic acid 
produces $N$-methyl-3-salicyloyl pyrrole $\mathbf{2 1 4}$ in high yield (Scheme 100) [119].

Condensation of 3-formylchromone 1a with $N^{1}, N^{2}$-dimethyl glycinamide (215) and L-pyrrolinamide 216 afforded chromonylimidazolinone $\quad \mathbf{2 1 7} \quad(79 \% \quad$ yield $)$ and pyrroloimidazolinone 218 (84\% yield), respectively, these reactions proceed via $[4+1]$ recyclization (Scheme 101) $[73,147]$.

As a result, a variety of products were obtained from the reaction of 3 -formylchromones with secondary amines depending on the nucleophile used.

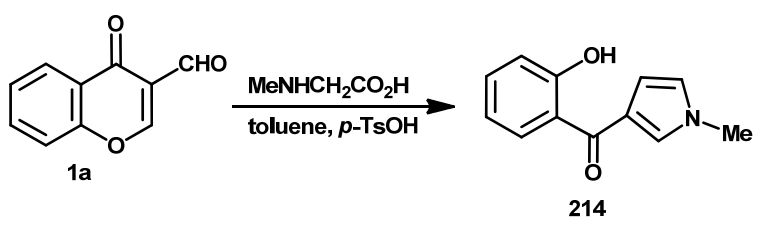

Scheme 100

\subsubsection{Reactions with tertiary amines}

The acid-catalyzed condensation of 3-formylchromone (1a) with a range of tertiary aromatic amines gave the 3-[bis(4aminophenyl)methyl]chromones $\mathbf{2 1 9}$ in moderate yield (Scheme 102) [148].

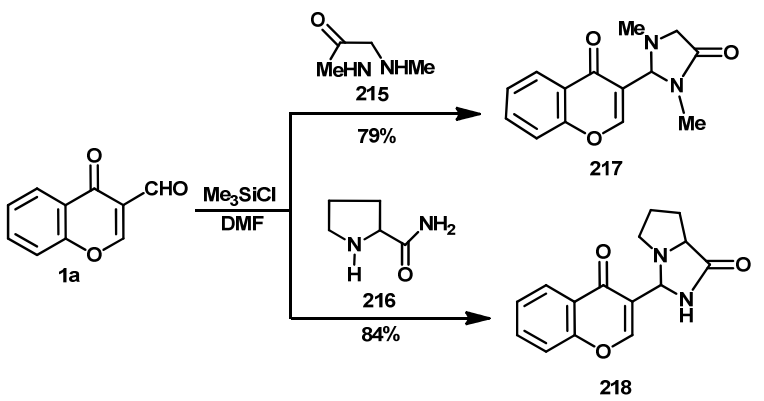

Scheme 101

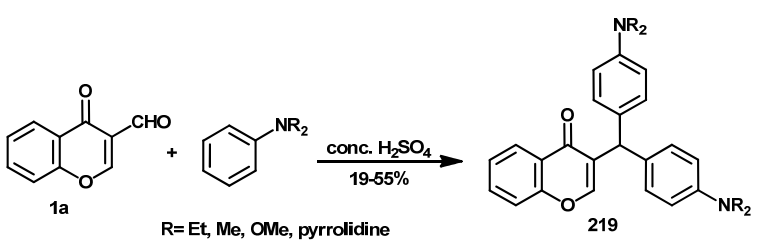

Scheme 102

\subsubsection{Reactions with hydrazines}

The reaction of 3-formylchromones 1a-d with hydrazines gave initially hydrazones $\mathbf{2 2 0}$ which then reacted further at the C-2 position to give 4-(2-hydroxybenzoyl)pyrazoles 212 (Scheme 103) [149-151].

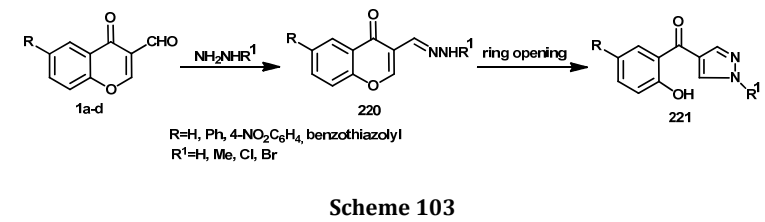

Treatment of 3-formylchromone 1a with substituted hydrazines 222a-c in absolute ethanol or toluene afforded the corresponding hydrazones 223a-c (Scheme 104) [152,153].

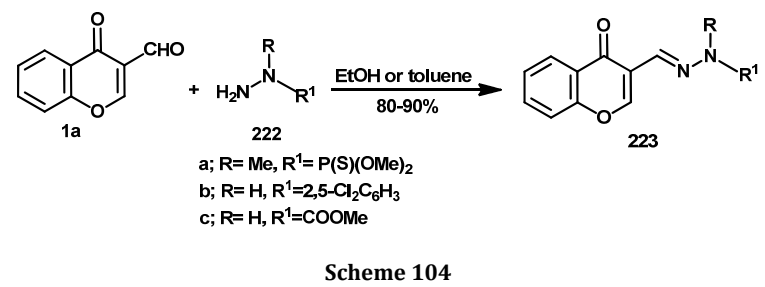

\subsubsection{Reactions with hydroxylamine}

The reaction of 3-formylchromone (1a) with hydroxylamine hydrochloride (1:2 molar ratio) afforded a mixture of pyrazole 224 and chromone 225 (Scheme 105) $[154,155]$.<smiles>C[C@H](N)c1cccc(C(=O)c2cn[nH]c2O)c1O</smiles>

Scheme 105

Treatment of 3-formylchromones (1a-d) with hydroxylamine hydrochloride in ethanol gave the corresponding oximes $\mathbf{2 2 6}$ which on dehydration by acetic anhydride gave chromone-3-carbonitriles 227 . When the reaction of 1a-d with hydroxylamine hydrochloride took place in the presence of sodium formate containing $\mathrm{HCl}$, the carbonitriles 227 were obtained directly. On the other hand, Oximination of 1a and its oxime 225 using hydroxylamine in sodium hydroxide led to 2-aminochromone-3-carboxamide (228) and 3-amino-4H-chromeno[3,4- $d]$ isoxazol-4-one (229), respectively (Scheme 106) [156-158].

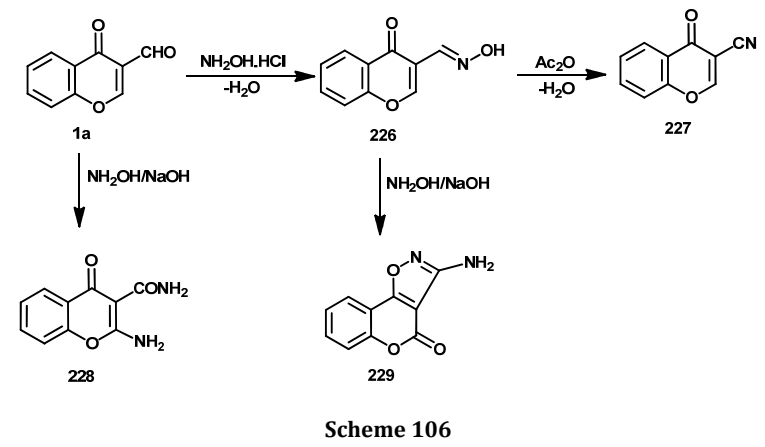

Nitrones 230 were prepared from the reaction of aldehydes 1a-c with hydroxylamine in ethanol. Nitrones 230 rearranged to 2-amino-3-formylchromones 231 in ethanol containing few drops of acetic acid in the presence of zinc (Scheme107) [159,160].

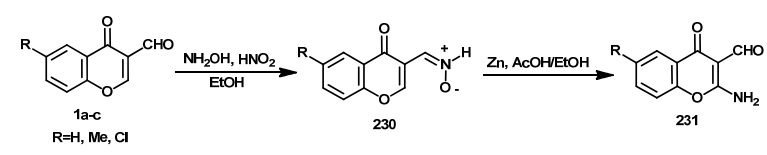

Scheme 107

Hence, hydroxylamine on reactions with 3formylchromones gave diverse types of products depending on the reaction conditions. 


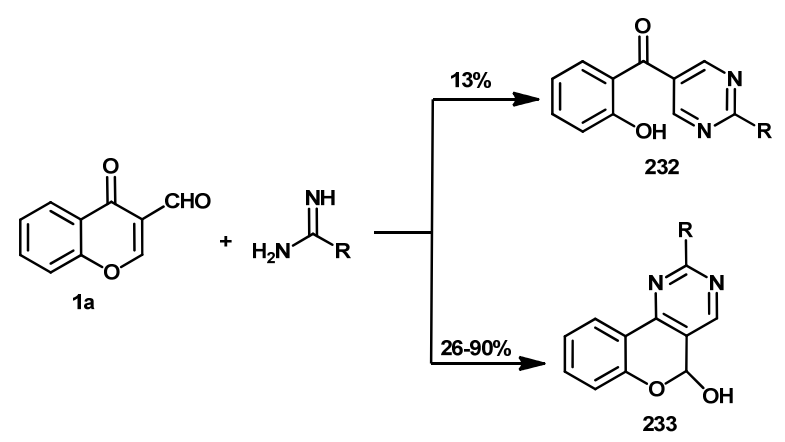

Scheme 108

\subsubsection{Reactions with amidines}

Reaction of 3-formylchromone 1a with formamidine gave a mixture of 5-(2-hydroxybenzoyl) pyrimidine $232(\mathrm{R}=\mathrm{H}, 13 \%)$ and 5-hydroxy-5H-chromeno[4,3- $d]$ pyrimidine $233(\mathrm{R}=\mathrm{H}$, $31 \%$ ) as reported by Loewe [161] While, reaction of 1 a with several $C$-substituted formamidines ( $\mathrm{R}=$ alkyl, aryl, hetaryl, $\mathrm{NH}_{2}$, NHCN, SH, SMe, OH, OMe, 1-pyrrolidinyl, 1-piperidinyl, 4morpholinyl) gave only chromeno-pyrimidines 233 in $26-90 \%$ yields (Scheme108) [161-166].

Thus, 3-formylchromones are a good precursors for the synthesis of pyrimidine derivatives via treatment with amidine derivatives as 1,3-bifunctional nucleophiles.

\subsubsection{Reactions with hyrazides}

3-Formylchromones 1a-d reacted with semicarbazide and thiosemicarbazide in ethanol to give the corresponding semicarbazones 234a $(X=0)$ and thiosemicarbazone 234b $(X=S)$, respectively (Scheme109) $[150,167,168]$.

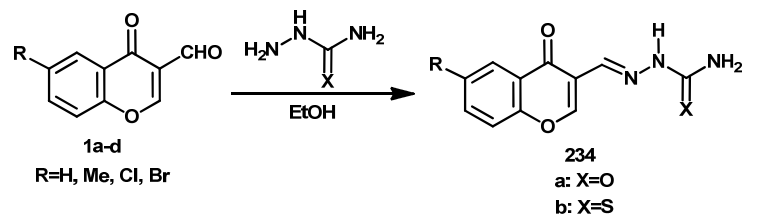

Scheme 109

The reaction of 3-formylchromone 1a-d with aroylhydrazines gave the corresponding aroylhydrazone 235 (Scheme110) [169-172].

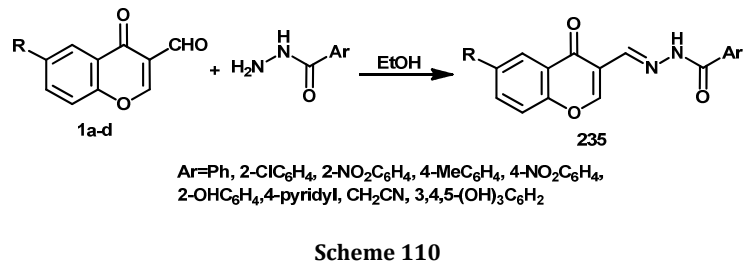

3-Formylchromone 1c condensed with equimolar amount of hydrazine carbodithioic acid and thiocarbohydrazide in ethanol to give the corresponding hydrazones 236 and 237, respectively. Also, condensation of $\mathbf{1 c}$ with two equivalents of thiocarbohydrazide gave bis thiocarbohydrazone derivative 238 (Scheme111) [173].

Phosphorohydrazone of chromone $\mathbf{2 3 9}$ was obtained from stirring 3-formylchromone 1a with diethoxythiophosphorylhydrazide inethanol (Scheme112) [159].

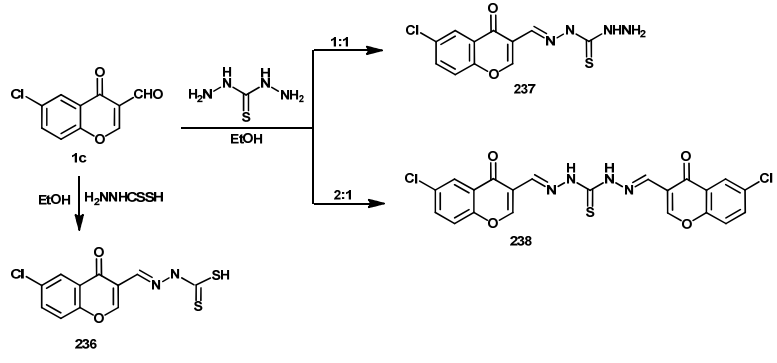

Scheme 111

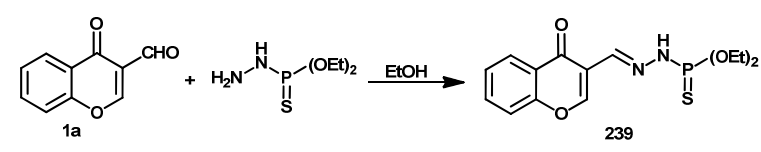

Scheme 112

\section{Conclusion}

In the present work, the chemical reactivity of 3formylchromones was evaluated and summarized towards all types of carbon and nitrogen nucleophiles under different reaction conditions.3-Formylchromones are very active toward the nucleophilic reagents, due to the availability of three electron deficient sites, the aldehydes carbon, $C-2$ carbon, and the $C-4$ carbon of the carbonyl group. A variety of fused heterocyclic systems were prepared directly from the reaction of 3-formylchromones with some bifunctional nucleophiles, these reactions mainly proceed via condensation with the aldehydic function followed by nucleophilic attack at C-2 position of the chromone moiety.

\section{References}

[1]. Reynolds, G. A.; Van Allan, J. A. J. Heterocycl. Chem. 1969, 6, 375-377.

[2]. Harnisch, H. Liebigs Ann. Chem. 1973, 765, 8-14.

[3]. Nohara, A.; Umetani, T.; Sanno, Y. Tetrahedron Lett. 1973, 14, 19951998.

[4]. Nohara, A.; Umetani, T.; Sanno, Y. Tetrahedron 1974, 30, 3553-3561.

[5]. Prakash, O.; Kumar, R.; Sharma, D.; Bhardwaj, V. J. Indian Chem. Soc. 2004, 81, 888-890.

[6]. Klutchko, S.; Cohen, M. P.; Shavel J. J.; Von Standtmann, M. J. Heterocycl. Chem. 1974, 11, 183-188.

[7]. Becket, G. J. P.; Ellis, G. P. Tetrahedron Lett. 1976, 17, 719-720.

[8]. Ellis, G. P. J. Chem. Res (S). 1978, 47-48.

[9]. El-Shaaer, H. M. E.; Prejessy, A.; Zahradik, P.; Lacova, M.; Sustekova, Z. Monatch Chem. 1993, 124, 539-548.

[10]. Eiden, F.; Haverland, H. Arch. Pharm. 1996, 5, 29-33.

[11]. Paul, S.; Gupta, R.; Gupta, M.; Loupy, A. Synthesis 2002, 75-78.

[12]. Shim, Y. S.; Kim, K. C.; Chi, D. Y.; Lee, K. H.; Cho, H. Bioorg. Med. Chem. Lett. 2003, 13, 2561-2563. 
[13]. Shrestha, S.; Hwang, S. Y.; Lee, K. H.; Cho, H. Bull. Korean Chem. Soc. 2005, 26, 1138- 1140 .

[14]. Nandgaonkar, R. G.; Ingle, V. N. Asian J. Chem 2005, 17, 2016-2018.

[15]. Kamotra, P.; Gupta, A.K.; Gupta, R.Indian J. Chem. B 2007, 46, 866-868.

[16]. Hatzade, K. M.; Taile, V. S.; Gaidhane, P. K.; Umare, V. D.; Haldar, A. G. M.; Ingle, N. V. Indian J. Chem. B 2009, 48, 1548-1557.

[17]. Ibrahim, S. S.; Allimony, H. A.; Abdel-Halim, A. M.; Ibrahim, M. A. Arkivoc 2009, 14, 28-38.

[18]. Patil, L. R.; Ingle, V. S.; Bondge, S. P.; Mane, R. A. Indian J. Chem. 2001, 41B, 131-134

[19]. Shankar, M. S. S.; Reddy, R. B.; Chandra, M. G. V. P.; Reddy, Y. D. J. Indian Chem. Soc. 1989, 66, 30-35.

[20]. Tuskaev, V. A.; Oganesyan, E. T.; Mutsueva, S. K. Pharm. Chem. J. 2002, 36, 309-312.

[21]. Hatzade, K. M.; Taile, V. S.; Gaidhane, P. K.; Halder, A. G. M.; Ingle, V. N. Indian J. Chem. $B$ 2008, 47, 1260-1270.

[22]. Abass, M.; Abdel-Megid, M.; Hassan, M. Synth. Commun. 2007, 37, 329 352.

[23]. Abass, M.; Hassan, A. Chem. Pap. 2003, 57, 267-277.

[24]. Abdel-Megid, M.; Gabr, Y.; Awas, M. A.; Abdel-Fattah, N. M. Chem. Heterocycl. Compds. 2009, 45, 1354-1364.

[25]. Siddiqui, Z.N.; Musthafa, T. N. M. Tetrahedron Lett. 2011, 52, 40084013.

[26]. Mustafa, T. N. M.; Siddiqui, Z. N.; Husain, F. M.; Ahmad, I. Med. Chem. Res. 2010, 19, 1473-1481.

[27]. Siddiqui, Z. N.; Asad, M.; Praveen, S. Med. Chem. Res. 2008, 17, 318325.

[28]. El-Shaaer, H. M. Eur. J. Chem. 2012, 3, 51-56.

[29]. Melikyan, G.; Lacova, M.; Kralova, K.; El-Shaaer, H. M.; Henselova, M.; Avetisyan, A. A. Chem. Pap. 1993, 47, 388-392.

[30]. Lacova, M.; El-Shaaer, H. M.; Loss, D.; Matulova, M.; Chovancova, J.; Furdik, M. Molecules 1998, 3, 120-131.

[31]. Caujoll, R.; Baziard-Mouysset, G.; Favort, J. D.; Payard, M.; Loiseau, P. R.; Amaroush, H.; Linas, M. D.; Seguela, J. P.; Loiseau, P. M.; Bories, C.; Gayral, P. Eur. J. Med. Chem. 1993, 28, 29-35.

[32]. Gasparova, R.; Lacova, M.; El-Shaaer, H. M.; Odlerova, Z. II Farmaco 1997, 52, 251-352.

[33]. Achaiah, G.; Jayamma, Y.; Reddy, V. M. Indian J. Heteterocycl. Chem. 1991, 1, 139-143.

[34]. Karale, B. K.; Gill, C. H.; Ganages, K. N.; Bachute, M. T.; Shingare, M. S. Indian J. Heterocycl. Chem. 1999, 9, 153-154.

[35]. Karale, B. K.; Gill, C. H.; Ganage, K. N.; Bachute, M. T.; Shingare, M. S. Indian J. Heterocycl. Chem. 2003, 12, 267-270.

[36]. Carvaiho, S. A.; Desilva, E. F.; Desouza, M. N. N.; Lourence, M. C. S.; Reckova, R. R. F. Bioorg. Med. Chem. Lett. 2008, 18, 538-541.

[37]. Joshi, R. S.; Mandhane, P. G.; Badadhe, P. V.; Gill, C. H. Ultrason. Sonochem. 2011, 18, 735-738.

[38]. Nohara, A.; Kuriki, H.; Saijo, T.; Ukawa, K.; Murata, T.; Kanno, M.; Sanno, Y. J. Med. Chem. 1975, 18, 34-37.

[39]. Karale, B. K.; Chavan, V. P.; Hangarge, R. V.; Mane, A. S. Indian J. Heterocycl. Chem. 2001, 11, 81-82.

[40]. Halnor, V. B.; Dalvi, N. R.; Joshi, N. S.; Gill, C. H.; Karale, B. K. Indian J. Chem. $B$ 2006, 45, 288-291.

[41]. Lacova, M.; Stankovcova, H.; Bohac, A.; Kotzianova, B. Tetrahedron 2008, 64, 9646-9653.

[42]. Lacova, M.; GaSparova, R.; Kois, P.; Bohac, A.; El-Shaaer, H. M. Tetrahedron 2010, 66, 1410-1419.

[43]. Kovacikova, L.; GaSparova, R.; Bohac, A.; Durana, M.; Lacova, M. Arkivoc 2010, 11, 188-203.

[44]. Shingare, M. S.; Karale, B. K.; Gill, C. H.; Ganage, K. N.; Bachute, M. T. Indian J. Heterocycl. Chem. 1999, 9, 153-154.

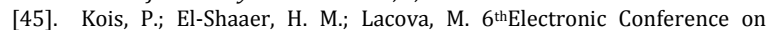
Synthetic Organic Chemistry, ECSOC-9, September 1-30, 2005.

[46]. Nohara, A.; Umetani, T.; Sanno, Y. Jap. Patent, 1975, 7, 552067; C. A., 1976, 84, 105400t.

[47]. Nohara, A.; Kuriki, H.; Saijo, T.; Sugihara, H.; Kanno, M.; Sanno, Y. J. Med. Chem. 1977, 20, 141-145.

[48]. Gill, C. H.; Karale, B. K.; Dalvi, N. R. Indian J. Chem. B 2005, 44, 15221525.

[49]. Diwakar, S. D.; Bhagwat, S. S.; Shingare, M. S.; Gill, C. H. Bioorg. Med. Chem. Lett. 2008, 18, 4678-4681.

[50]. Luengo, J. I.; Elliott, J. D.; Xiang, J. N. PCT. Int. Appl. Wo. 97 04, 773; C. A., 1997, 126, 225307g.

[51]. Nadiu, M. S. R.; Nadiu, R. R. Indian J. Chem. B 1997, 36, 99-100.

[52]. Prousek, J.; Jurasek, A.; Kovac, J. Coll. Czech. Chem. Commun. 1980, 45, 1704-1706.

[53]. Jones W. D.; Albrecht, W. L. J. Org. Chem. 1976, 41, 706-707.

[54]. Bandyophadyaya, C.; Sur, K. R.; Patra, R. J. Chem. Res. (s). 1998, 12, 802-803.

[55]. Borrell, J. I.; Teixido, J.; Schuler, E.; Michelotti, E. L. Molecular Diversity 2000, 5, 163- 166

[56]. Hangarge, R. V.; Sonwane, S. A.; Jarikote, D. V.; Shingare, M. S. Green Chem. 2001, 3, 310-312.

[57]. Chandra, K. G.; Samita, B.; Nanda, G.; Basudeb, A. J. Chem. Res(s). 1998, 178-179.
[58]. Saha, S. S.; Ghosh, T.; Tarun, G.; Bandyopadhyay, C. Synth. Commun. 2008, 38, 2429-2436.

[59]. Awas, M. A. A. Chem. Pap. 2006, 60, 338-347.

[60]. Nohara, A.; Ishiguro, T.; Sanno, Y. Tetrahedron Lett. 1974, 13, 1183 1186.

[61]. Abdel-Rahman, A. H.; Hammouda, M. A. A.; El-Desoky, S. I. Heteroatom. Chem. 2005, 16, 20-27.

[62]. Heber, D. Synthesis 1978, 691-692.

[63]. Ghosh, C. K.; Khan, S. Synthesis 1981, 903-907.

[64]. Ghosh, C. K. Heterocycles 2004, 63, 2875-2898.

[65]. Terzidis, M.; Tsoleridis, C. A.; Stephanidou-Stephanatou, J. Tetrahedron 2007, 63, 7828-7862.

[66]. Von Harnish, H. Justus Lieb. Ann. Chem. 1972, 765, 25-33.

[67]. Copeland, R. A. B.; Day, A. R. J. Am. Chem. Soc. 1943, 65, 1072-1075.

[68]. Brzozowski, Z.; Saczewski, F. Eur. J. Med. Chem. Chem. 2002, 37, 709720.

[69]. Ryabukhin, S. V.; Plaskon, A. S.; Volochnyuk, D. M.; Tolmachev, A. A. Synthesis 2 007, 3155-3162.

[70]. Sarma, G. V. S. R.; Reddy, V. M. Indian J. Heterocycl. Chem. 1993, 3, 111116.

[71]. Fitton, A. O.; Frost, J. R.; Suschitzky, H.; Houghton, P. G. Synthesis 1977, 133-134.

[72]. Sabitha, G.; Reddy, M. M.; Archana, B.; Yadav, J. S. Synth. Commun. 1998, 28, 573-581.

[73]. Plaskon, A. S.; Ryabukhin, S. V.; Volochnyuk, D. M.; Shivanyuk, A. N.; Tolmachev, A. A. Tetrahedron 2008, 64, 5933-5943.

[74]. Naskar, S.; Banerjee, M.; Hazra, A.; Mondal, S.; Maity, A.; Paira, R.; Sahu K. B.; Saha, P.; Banerjee, S.; Mondal, N. B. Tetrahedron Lett. 2011, 52, $1527-1531$.

[75]. Polyakov, V. K.; Shevtsova, R. G.; Tsukerman, S. Ukr. Khim. Zh, 1981, 47, 85-87.

[76]. Haas, G.; Stanton, J. L.; Von Sprecher, A.; Wenk, P. J. Heterocycl. Chem. 1981, 18, 607- 612 .

[77]. Singh, P.; Kaur, M.; Holzer, W. Eur. J. Med. Chem. 2010, 45, 4968-4082.

[78]. Karale, B. K.; Chavan, V. P.; Mane, A. S.; Hangarge, R. V.; Gill, C. H.; Shingare, M. S. Synth. Commun. 2002, 32, 497-503.

[79]. Siddiqui, Z. N.; Musthafa, T. N. M.; Praveen, S. Med. Chem. Res. 2013, $22,127-133$.

[80]. Khodairy, A. J. Chinese Chem. Soc. 2007, 54, 93-102.

[81]. Shelke, S. N.; Dalvi, N. R.; Kale, S. B.; More, M. S.; Gill, C. H.; Karale B. K. Indian J. Chem. B 2007, 46, 1174-1178.

[82]. Abbas, M.; Othman, E. S.; Hassan, A. Synth. Commun. 2007, 37, $607-$ 621.

[83]. Lacova, M.; GaSparova, R.; Loos, D.; Liptay, T.; Pronayova, N. Molecules 2000, 5, 167- 178 .

[84]. Bozdag-Dundar, O.; Evranos, B.; Das-Evcimen, N.; Sarhkaya, M.; Ertan R. Eur. J. Med. Chem. 2008, 43, 2412-2417.

[85]. Verspohl, E. J.; Bozdağ-Dündar, O.; Kaup, R. M.; Bauer, K.; Ertan, R. Med. Chem. Res. 2009, 18, 665-670.

[86]. Ibrahim, M. A.; Abdel-megid, M.; El-Gohary, N. M. J. Braz. Chem. Soc. 2011, 21, 1130- 1139.

[87]. GaSparova, R.; Lacova, M. Coll. Czech. Commun. 1995, 60, 1178-1183.

[88]. Franz, C.; Heinisch, G.; Holzer, W.; Mereiter, K.; Strobe, B.; Zheng, C. Heterocycles 1995, 41, 2527-2551.

[89]. Shutov, R. V.; Kukline, E. V.; Ivin, B. A. Russ. J. Gen. Chem. 2009, 79, 1049-1051.

[90]. Eiden, F.; Haverland, H. Arch. Pharm. 1967, 300, 806-809.

[91]. Shelke, K. F.; Sapkal, K. S. B.; Niralwad, S.; Shingate, B. B.; Shingate, M. S. Cent. Eur. J. Chem. 2010, 8, 12-18.

[92]. Shindalkar, S. S.; Madje, B. R.; Shingare, M. S. Indian J. Chem. B 2006 45, 2571-2573.

[93]. Prousek, J. Coll. Czech. Chem. Commun. 1991, 56, 1361.

[94]. Reddy, K. V.; Rao, A. V. S. Org. Prep. Proc. Int. 1997, 29, 355-357.

[95]. Sosnovskikh, V. Y.; Irgashev, R. A.; Levchenko, A. A. Tetrahedron 2008 64, 6607-6614.

[96]. Teimouri, M. B. Tetrahedron 2011, 67, 1837-1843.

[97]. Bandyopadhyay, C.; Sur, K. R. Indian. J. Chem. B 2000, 39, 137-140.

[98]. Ibrahim, M. A.; Hassanin, H. M.; Gabr, Y. A.; Alnamer, Y. A. Eur. J. Chem. 2010, 3, 195-199.

[99]. Hassanin, H. M.; Ibrahim, M. A.; Alnamer, Y. A. Turkish J. Chem. 2012, $36,682-699$.

[100]. Fitton, A. O.; Frost, J. R.; Suschitzky, H. Tetrahedron Lett. 1975, 16, 2099-2100.

[101]. Sigg, I.; Haas, G.; Winkler, T. Helv. Chim. Acta 1982, 65, 26.

[102]. Achaiah, C.; Reddy, V. Indian J. Pharm. Sci. 1991, 53, 253-255.

[103]. Chen, H. M.; Cao, L. H. J. Chinese Chem. Soc. 2009, 56, 1028-1034.

[104]. Kapur, A.; Kumar, K.; Singh, L.; Singh, P.; Elango, M.; Subramanian, V.; Gupta, V.; Kanwal, P.; Ishar, M. P. S. Tetrahedron 2009, 65, 4593-4603.

[105]. Khan, K. M.; Ambreen, N.; Hussain, S.; Perveen, S.; Choudhary, M. I. Bioorg. Med. Chem. 2009, 17, 2983-2988.

[106]. Khan, K. M.; Ambreen, N.; Mughal, U. R.; Jalil, S.; Perveen, S.; Choudhary, M. I. Eur. J. Med. Chem. 2010, 45, 4058-4064.

[107]. Dziewulska-Kulaczkowska, A. J. Therm. Anal. Calorim. 2012, 109, 7-15.

[108]. El-Shaaer, H. M.; Abdel-Aziz, S. A. A.; Hanafy, F. I.; Ali, T. E.; El-Fayomy, A. Z. Eur. J. Chem. 2011, 2, 158-162.

[109]. Fitton, A. O.; Haughyo, G.; Suschitzky, H. Synthesis 1979, 337-339. 
[110]. Lacova, M.; Stankovicova, H.; Odlerova, Z. II Farmaco 1995, 50, 885888.

[111]. Fitton, A. O.; Frost, J. R.; Houghton, P. G.; Suschitzky, H. J. Chem. Soc. , Perkin Trans. 1 1977, 1450-1452.

[112]. El-Shaaer, H. M.; Foltinova, P.; Lacova, M.; Chovancova, J.; Stankovicova, H. II Farmaco 1998, 53, 224-232.

[113]. Stankovicova, H.; Lacova, M.; Gaplovsky, A.; Chovancova, J.; Pronayova, N. Tetrahedron 2001, 57, 3455-3464.

[114]. Al-Rashida, M.; Ashraf, M.; Hussain, B.; Nagra, S. A.; Abbas, G. Bioorg. Med. Chem. 2011, 19, 3367-3371.

[115]. Dziewulska-Kulaczkowska, A.; Mazur, L. J. Mol. Struct. 2011, 985, 233244.

[116]. Plaskon, A. S.; Ryabukhin, S. V.; Volochnyuk, D. M.; Gavrilenko, K. S.; Shivanyuk, A. N.; Tolmachev, A. A. J. Org. Chem. 2008, 73, 6010-6013.

[117]. Ryabukhin, S. V.; Plaskon, A. S.; Volochnyuk, D. M.; Tolmachev, A. A. Synthesis 2007, 1861-1871.

[118]. Kalanithi, M.; Kodimunthiri, D.; Rajarajan, M.; Tharmaraj, P. Spectrochim. Acta A 2011, 82, 290-298.

[119]. Clarke, P. D.; Fitton, A. O.; Kosmirak, M.; Suschitzky, H.; Suschitzky, J. L. J. Chem. Soc. , Perkin Trans. 1 1985, 1747-1756.

[120]. Ghosh, C. K.; Ray, A.; Patra, A. J. Heterocycl. Chem. 2001, 38, 14591463.

[121]. Fitton, A. O.; Kosmirak, M.; Suschitzky, H. Tetrahedron Lett. 1982, 23, 3953-3956.

[122]. Nogueras, M.; Sanchez, A.; Cobo, J.; Low, J. N. J. Heterocycl. Chem. 2002, 49, 51-54.

[123]. Lacova, M.; Puchala, A.; Solčanyova, E.; Lac, J.; Kois, S.; Chovancova, J.; Rsala, D. Molecules 2005, 10, 809-821.

[124]. Eynde, J. J. V.; Hecq, N.; Kataeva, O.; Kappe, C. O. Tetrahedron 2001, 57, 1785-1791.

[125]. Quiroga, D.; Rengifo, A.; Insuasty, B.; Abonía, R.; Nogueras, M.; Sanchez, A. Tetrahedron Lett. 2002, 43, 9061-9063.

[126]. Abonia, R.; Insusty, B.; Quiroga, J.; Kolshorn, H.; Meier, H. J. Heterocycl. Chem. 2001, 38, 671-674.

[127]. Kubicova, L.; Pour, M.; Lacova, M.; Kralova, K.; Chovancova, J.;

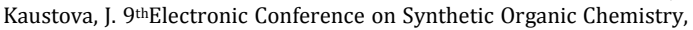
ECSOC-9, September 1-30, 2002.

[128]. Reddy, G. J.; Sabitha, M. G.; Rao, A. V. S. Synth. Commun. 1987, 17, 1851-1859.

[129]. Plaskon, A. S.; Ryabukhin, S. V.; Volochnyuk, D. M.; Shivanyuk, A. N.; Tolmachev, A. A. Heterocycles 2008, 75, 1765-1772.

[130]. Ghosh, C. K.; Khan, S. Synthesis 1980, 9, 701-702.

[131]. Reddy, G. J.; Rao, A. V. S. Curr. Sci. 1981, 50, 84-86

[132]. Sigg, I.; Haas, G.; Winkler, T. Helv. Chim. Acta 1982, 65, 275-279.

[133]. Rihs, G.; Sigg, I.; Haas, G.; Winkler, T. Helv. Chim. Acta 1985, 68, $1933-$ 1935.

[134]. Risitano, F.; Grassi, G.; Foti, F. J. Heterocycl. Chem. 2001, 38, 10831086.

[135]. Abdel-Rahman, A. H.; Khalil, A. M.; Keshk, E. M. Boll. Chim. Farm. 2001, 140, 387-396

[136]. Grolik, J.; Zwolinski, K.; Eilmes, J.; Sieron, L. Tetrahedron 2011, 67, 2623-2632.

[137]. Grolik, J.; Sieron, L.; Eilmes, J. Tetrahedron Lett. 2006, 47, 8209-8213.

[138]. Das, B.; Holla, H.; Srinivas, Y. Tetrahedron Lett. 2007, 48, 61-64.

[139]. Maiti, S.; Panja, S. K.; Bandyopadhyay, C. Indian J. Chem. 2009, 48B, 1447-1452.

[140]. El-Desoky, E. I.; Al-Shihry, S. S. J. Heterocycl. Chem. 2008, 45, 18551864.

[141]. Das, B.; Kanth, B. S.; Reddy, K. R.; Kumar, A. S. J. Heterocycl. Chem. 2008, 45, 1499- 1502 .

[142]. Ali, T. E.; Ibrahim, M. A. J. Braz. Chem. Soc. 2010, 21, 1007-1016.

[143]. Ali, T. E.; Abdel-Aziz, S. A.; El-Shaaer, H. M.; Hanafy, F. I.; El-Fauomy, A. Z. Turk. J. Chem. 2008, 32, 365-374.

[144]. Ghosh, C. K.; Khan, S. Synthesis 1981, 719-720.

[145]. Shelke, S. N.; Dalvi, N. R.; Shingare, M. S.; Gill, C. H.; Karale, B. K. Indian J. Heterocycl. Chem. 2006, 15, 403-404.

[146]. Sharad, N. S.; Sonawane, M. P.; Karale, B. K.; Gill, C. H. Nature Precedings 2009, 1, 2855-2862.

[147]. Pospisil, J.; Potacek, M. Heterocycles 2004, 63, 1165-1173.

[148]. Gabbutt, C. D.; Hargrove, T. F. L.; Heron, B. M.; Jones, D.; Poyner, C.; Yildiz, E.; Horton, P. N.; Hursthouse, M. B. Tetrahedron 2006, 62, 10945-10953.

[149]. Ghosh, C. K.; Mukhopdyaya, K. K. J. Indian Chem. Soc. 1978, 55, 52-55.

[150]. Ghosh, C. K.; Mukhopdyaya, K. K. J. Indian Chem. Soc. 1978, 55, 386388.

[151]. Reddy, G. J.; Sbitha, G.; Rao, A. V. S. Indian J. Chem. B 1984, 23, 99-103.

[152]. Nawrot-Modranka, J.; Nawrot, E.; Graczyk, J. Eur. J. Med. Chem. 2006, 41, 1301-1309.

[153]. Lazrenkow, A.; Nawrot-Modranka, J.; Brzeziska, E.; Krojewska, U. R.; Ozalski, M. Med. Chem. Res. 2012, 21, 1861-1868.

[154]. Ghosh, C. K.; Sinharoy, D. K.; Mukhopadhyaya, K. K. J. Chem. Soc., Perkin Trans. 1 1979, 1981-1985.

[155]. Bosinski, W.; Jerzmanowska, Z. Pol. J. Chem. 1983, 57, 471-474.

[156]. Petersen, U.; Heitzer, H. Liebigs Ann. Chem. 1976, 1663-1666.

[157]. Sosnovskikh, V. Y.; Moshkin, V. S.; Kodess, M. I.; Tetrahedron Lett. 2008, 49, 6856- 6859.
[158]. Sosnovskikh, V. Y.; Moshkin, V. S.; Kodess, M. I. Mendeleev Commun 2010, 20, 209- 211.

[159]. Maiti, S.; Panja, S. K.; Bandyopodhyay, C. Tetrahedron Lett. 2009, 50, 3966-3969.

[160]. Ishar, M. P. S.; Kumar, K.; Singh, R. Tetrahedron Lett. 1998, 39, $6547-$ 6550.

[161]. Lowe, W. Synthesis 1976, 274-276.

[162]. Ghosh, C. K.; Khan, S. C. Indian J. Chem. B 1979, 18, 128-130.

[163]. Pene, C.; Hubert-Habart, M. J. Heterocycl. Chem. 1980, 17, 61-64.

[164]. Crowther, A. F.; Curd, F. H. S.; Richardson, D. N.; Rose, F. L. J. Chem. Soc. 1984, 1636

[165]. Borrell, J. I.; Teixido, J.; Schuler, E.; Michelotti, E. Tetrahedron Lett 2001, 42, 5331- 5334.

[166]. Bruno, O.; Brullo, C.; Ranis, A.; Schenone, S.; Bondavalli, F.; Barocelli, E.; Chivarini, M.; Ballabeni, V.; Impicciatore, M.; Tognolini, M. Bioorg. Med. Chem. Lett. 2011, 11, 1397-1400.

[167]. Tsao, L.; Van, V.; Sun, G.; Lyu, Y. Russ. J. Gen. Chem. 2001, 71, 767-769.

[168]. Cao, L. H.; Huang, Y. L. Y. T.; Sun, G. Z. Yingyong Huaxue 2001, 18, $312-$ 313.

[169]. Foltinova, P.; Lacova, M.; Loss, D. II Farmaco 2000, 55, 21-26.

[170]. Cao, L.; Wang, W. Chem. Heterocycl. Compd. 2003, 39, 1072-1075.

[171]. Wang, B. D.; Yang, Z. Y.; Zhang, D. W.; Wang, Y. Spectrochim. Acta A 2006, 63, 213-219

[172]. Tsao, L.; Chzhan, L.; Lyu, T. Chem. Nat. Compd. 2001, 37, 311-314

[173]. Ali, T. E.; Abdel-Aziz, S. A.; El-Shaaer, H. M.; Hanafy, F. I.; El-Fauomy, A. Z. Phosphorous, Sulfur and Silicon Rel. Elem. 2008, 183, 2139-2160. 